\title{
JURISDICTIONAL PROBLEMS IN CANADA'S OFFSHORE
}

\author{
K. BEAUCHAMP, M. CROMMELIN, and A. R. THOMPSON*
}

As oil and gas exploration activities are beginning to concentrate in offshore regions, it is inevitable that two major problems will be encountered: (1) international boundaries; and (2) federal-provincial control over offshore resources. The authors devote the first part of their paper to a discussion of the first problem. They analyze the historical origin of offshore rights; current international law on the subject; various methods of determining boundaries; followed by a detailed examination of six of Canada's present boundary disputes and the corresponding position taken by the concerned countries in each case. The latter part of the paper is devoted to the federal-provincial issue, concentrating on constitutional aspects, resource sharing, and admin. istration of the offshore operation. The authors critically analyze the Offshore Minerals Reference case, and proceed to a comparative study between Canada, Australia, and the United States with respect to the control, development and exploitation of offshore resources. The federal offer to the provinces, consisting of arbitrary boundaries for purposes of administration, is critically evaluated and rejected. In its place, the authors propose some viable alternatives. Finally, the applicability of ancillary federal and provincial laws to the offshore region is examined.

\section{INTRODUCTION}

Canada's submerged continental margin, which includes both the continental shelf and the continental slope seaward to the ocean depths, ${ }^{1}$ is estimated to cover almost two million square miles, an area about half as large as the total land area of Canada. It is the second largest in the world, exceeded only by that of the U.S.S.R. ${ }^{2}$

In recent years, areas of this continental margin have become highly prospective oil and gas exploration targets. To the end of 1971, fifty-two offshore wells had been drilled, thirty-seven off the east coast, fourteen off the west coast, and one in Hudson Bay. Thirty-three of these were drilled in the last two years. ${ }^{3}$ Plans provide for even more intense offshore activity in the next two years, especially in the areas of current interest, the east coast, the Beaufort Sea, and the high Arctic.

This paper seeks to highlight the issues that are presently raised by offshore oil and gas operations, issues that should be resolved by any effective, comprehensive legal regime that is established to govern these operations. In so doing, the paper falls into two parts. The first involves consideration of the nature and extent of the rights exercisable by Canada over the continental margin, rights which are the product of international law. The second is concerned with the allocation of these rights within the Canadian constitutional framework between the federal and provincial governments, the domestic law problems inherent in this allocation, and posssible solutions for these problems.

\footnotetext{
- K. Beauchamp is a third-year law student. Mr. Crommelin is a Ph.D. candidate in law and economics. Dr. Thompson is a professor of law. All are at the University of British Columbia.

1 The continental shelf is that submerged portion of a continent that dips gently seaward, on the average less than $1^{\circ}$, to a point where it merges into the slope' through an increase in gradient, on the average, to about $3 \frac{1}{2^{\circ}}$.

2 Crosby, Aspects of Offshore Mineral Resource Management, a paper delivered to the 26th Annual Conference of The Chemical Institute of Canada, Halifax, Nova Scotia, June 2, 1971.

3 Oilweek, February 21, 1972, at 76.
} 


\section{INTERNATIONAL DIMENSIONS}

\section{Offshore Rights}

The rights exercisable by Canada over the continental margin vary, depending upon whether the area in question comes within the limits of Canada's territorial sea, or lies beyond. The Convention on the Territorial Sea and the Contiguous Zone,${ }^{4}$ one of the four conventions adopted at the 1958 United Nations Conference on the Law of the Sea held at Geneva, Switzerland, recognizes that the sovereignty of a coastal nation extends beyond its land territory and its internal waters, to its territorial sea. ${ }^{5}$ This sovereignty is exercisable in respect of the waters of the territorial sea, the seabed and subsoil below, and the air space above. It is as complete a sovereignty as that exercisable by a nation in respect of its land territory, except for the reservations specified by the Convention, such as the right of ships of all nations to innocent passage through the territorial sea. ${ }^{6}$ The Convention also authorizes a coastal nation to exercise, in the zone of the high seas contiguous to its territorial sea, the control necessary to prevent the infringement of its customs, fiscal, immigration or sanitary regulations within its territory or territorial sea. ${ }^{7}$ The contiguous zone may not extend beyond twelve miles from the baselines from which the territorial sea is measured. ${ }^{8}$

One issue that the Convention on the Territorial Sea and the Contiguous Zone ${ }^{9}$ does not determine is the breadth of the territorial sea. One view that may be argued is that it cannot exceed twelve miles, the maximum extent of the contiguous zone, which by implication lies outside the territorial sea. Several nations, however, have made claims to territorial seas extending far beyond the twelve mile limit.10

Although Canada was a signatory to the Convention on the Territorial Sea and the Contiguous Zone in 1958, it has not ratified the Convention, and accordingly is not bound by its provisions. Nevertheless, this should not affect the nature of the rights exercisable by Canada over its territorial sea, as these rights would now be recognized by international law. Indeed, the reason why Canada has not ratified the Convention would seem to lie in the recent assertion by Canada of jurisdiction over certain activities conducted outside the contiguous zone, as defined in the Convention. The Territorial Sea and Fishing Zones Act Amendment ${ }^{11}$ increased the breadth of the territorial sea claimed by Canada from three nautical miles to twelve, ${ }^{12}$ and provided for fishing zones which extend in some cases beyond the twelve mile limit. ${ }^{13}$ Furthermore, the Arctic Waters Pollution Prevention Act ${ }^{14}$ purports to create a pollution control zone extending up to one hundred miles seaward from the coast, and to

4 U.N. Doc. A/CONF. 13/L.52, adopted April 27, 1958.

s Id. article 1.1.

- Id. articles 14-23.

Id. article 24.1

- Id. article 24.2

- Supra, n. 4.

in Argentina, Brazil, Ecuador, El Salvador, Panama and Uruguay have claimed territorial seas extending 200 miles seawards. Chile, Costa Rica, Nicaragua and Peru have also claimed exclusive rights over zones 200 miles wide for specific purposes such as fisheries, living and non-living resources. These claims have recently received support from Spain, Yugoslavia and the Peoples' Republic of China.

" R.S.C. 1970, c. 45.

12 Id. s. 1.

13 Id. 8.2.

it R.S.C. 1970 , c. 2. 
control the discharge of substances and regulate shipping within that zone.

Beyond the territorial sea, the rights of a coastal nation are far from being clearly defined. Prior to 1945 , there was no internationally recognized right of appropriation of submarine areas. However, in September of that year, the now-famous Truman Proclamation ${ }^{15}$ stated that:

... the Government of the United States regards the natural resources of the subsoil and seabed of the continental shelf beneath the high seas but contiguous to the coasts of the United States as appertaining to the United States [and] subject to its jurisdiction and control.

This gave rise to a number of claims by other coastal nations, but there was a decided lack of uniformity in these claims. ${ }^{16}$ The situation was not clarified until the 1958 United Nations Conference on the Law of the Sea, which adopted the Convention on the Continental Shelf.17

This Convention comprises a body of rules applicable to the continental shelf, as defined therein, and to the exploitation of the natural resources of the seabed and subsoil of the shelf by coastal nations. It became effective in 1964, following ratification by twenty-two nations. It was ratified by Canada in 1970.

The Convention provides that a coastal nation exercises "sovereign rights" over the continental shelf for the purpose of exploring it and exploiting its natural resources. ${ }^{18}$ These rights are exclusive, in the sense that if a coastal nation does not exercise them, no one else is entitled to do so without the express consent of that nation. ${ }^{19}$ Furthermore, these rights do not depend in any way upon occupation of the continental shelf, or upon proclamation. ${ }^{20}$

In many respects, the rights of a coastal nation over the continental shelf are considerably more restricted than the rights of a coastal nation over its territorial sea. Substantial difficulties may arise in determining the nature of the continental shelf rights. In the first place, a coastal nation is said to have "sovereign rights" over the continental shelf, as compared with "sovereignty" over its territorial sea. The former expression emphasizes that the rights over the continental shelf are limited to those which are linked with the specified purposes of exploration and exploitation of natural resources. Undoubtedly, border-line cases will arise in the future where it will be difficult to determine whether an activity conducted on the continental shelf is carried on for the required purpose. Secondly, the rights of a coastal nation over the continental shelf do not extend to the superjacent waters, which retain the legal status of high seas, or to the airspace above those waters. ${ }^{21}$ Thirdly, express restrictions are placed upon the rights of a coastal nation to explore the continental shelf and exploit its natural resources, and difficulties arise in any attempt to reconcile these restrictions with the rights upon which they operate. For example, a coastal nation, subject to its

\footnotetext{
1s Proclamation 2667, September 28, 1945.

${ }^{16}$ Krueger. The Development and Administration of the Outer Continental Shelf Lands of the United States, (1962) 14 Rocky Mountain Mineral Law Institute at 639 and 643.

17 U.N. Doc. A/CONF. 13/L.55, adopted April 26, 1958.

${ }^{18}$ Id. article 2.1.

19 Id. article 2.2 .

${ }^{20}$ Id. article 2.3.

21 Id. article 3.
} 
right to take "reasonable measures" for the exploration of the continental shelf and the exploitation of its natural resources, may not impede the laying or maintenance of submarine cables or pipelines on the continental shelf. ${ }^{22}$ Again, the activities of a coastal nation must not result in any "unjustifiable interference" with navigation, fishing, or the conservation of the living resources of the sea, nor any "interference" with "fundamental" oceanographic or other scientific research carried out with the intention of open publication. ${ }^{23}$ Finally, a coastal nation may construct and maintain or operate on the continental shelf "installations and other devices" necessary for its exploration and the exploitation of its natural resources, and may establish safety zones to a distance of 500 metres around such "installations and other devices", except where "interference" may be caused to the use of "recognized sea lanes essential to international navigation". ${ }^{24}$ Furthermore, a coastal nation is obliged to undertake, in such safety zones, "all appropriate measures" for the protection of the living resources of the sea from "harmful agents". 25

The natural resources of the continental shelf which may be exploited by the coastal nation are defined by the Convention as "the mineral and other non-living resources of the sea-bed and subsoil together with living organisms belonging to sedentary species". ${ }^{26}$ Although the scope of this definition is far from precise, it is clear that it includes hydrocarbons.

These rights of exploration and exploitation of natural resources are exercisable on the "continental shelf", which is defined in the Convention as follows: 27
(a) ... the seabed and subsoil of the submarine areas adjacent to the coast line but outside the area of the territorial sea, to a depth of 200 metres or, beyond that limit, to where the depth of the superjacent waters admits of the exploitation of the natural resource of the said areas; (b) ... the seabed and subsoil of similar submarine areas adjacent to the coasts of islands.

The ambiguity of this definition underlines the fact that there is no generally accepted international view as to how far seaward the limits of national jurisdiction over seabed resources should extend. Some nations have attached little importance to the "exploitability" test in the definition of the continental shelf, and have proposed that the 200 metres isobath be considered the outer limit of national jurisdiction. Others have claimed that the plain meaning of the definition is that it includes the entire continental margin, provided that exploitability of natural resources is established. In recent years, with the rapid development of offshore drilling technology, the question of the seaward limits of rights possessed by coastal nations has become a very important issue. Resolutions passed by the United Nations General Assembly in 1969 called for the convening of a further conference on the law of the sea in order to arrive at a "clear, precise and internationally accepted definition of the area of the sea-bed and ocean floor which lies beyond national jurisdiction", ${ }^{28}$ and demanded that nations refrain from all activities of ex-

\footnotetext{
22 Id. article 4.

23 Id. article 5.1.

24 Id. article 5.1, 5.2, 5.6.

${ }^{25}$ Id. article 5.7.

26 Id. article 2.4 .

27 Id. article 1.

2* 24 U.N. GAOR at U.N. Doc. A/2574A (1969).
} 
ploitation of the natural resources of the sea bed and subsoil of areas beyond the limits of national jurisdiction. ${ }^{29}$ There have also been motions calling for the establishement of an international regime to administer resources beyond national limits. ${ }^{30}$ Most recently, in May 1970, President Nixon announced a new United States oceans policy, which proposed a treaty to limit existing rights of coastal nations over the continental shelf to areas up to the 200 metres isobath, to establish a "trusteeship zone" in areas seaward of the limits of national jurisdiction to the edge of the continental margin, and to establish international machinery to administer the exploitation of the seabed resources of the ocean depths. ${ }^{31}$

Canada, however, has taken the view that the 200 metres isobath is an artificial limit with no real geologic-geographic significance, and that coastal nations should exercise exclusive rights over seabed resources out to the limits of their continental margins. ${ }^{32}$ In line with this view, offshore exploration permits have been issued in water depths ranging up to thousands of metres: to 2,200 metres in the Gulf of Maine region, to 3,700 metres in the Scotian Shelf region, to 3,000 metres in the Grand Banks region, to 2,800 metres in the Labrador Sea, to 900 metres in the Arctic Islands region, and to 2,600 metres in the Beaufort Sea. ${ }^{33}$

\section{Conclusions Re Offshore Rights}

The rights exercisable by Canada in offshore areas are dependent upon the current state of international law, which at present appears to be developing rapidly in response to the challenge offered by recent advances in offshore technology. It is, therefore, impossible to be precise in describing these rights. All that can be said is that within the limits of Canada's territorial sea, whatever may be the limits presently recognized by international law, these rights amount almost to sovereignty, subject to limited exceptions. Beyond the territorial sea, the rights are to explore the continental shelf, and to exploit its natural resources. All activities must, therefore, have the necessary link with at least one of these purposes before they are authorized by international law. Nevertheless, even activities conducted with the required purpose are not permitted where they infringe upon international rights of long standing, such as the freedom of navigation on the high seas. Finally, the seaward limit of exercise of national jurisdiction is the subject of international dispute, and must await further agreement for its definition.

\section{International Law Re Offshore Boundaries}

The principle for establishing international boundaries on the continental shelf between opposite and adjacent states is set out in Article 6 of the 1958 Geneva Convention on the Continental Shelf. ${ }^{34}$ This article sets forth the "median-line" principle:

\section{ARTICLE 6}

1. Where the same continental shelf is adjacent to the territories of two or more States whose coasts are opposite each other, the boundary of the continental shelf appertaining to such States shall be determined by agreement between them. In the absence of agreement, and unless another boundary line is justified by special circumstances,

\footnotetext{
24 U.N. GAOR at U.N. Doc. A/2574D (1969).

30 The first of these was the Malta proposal, U.N. Doc. A/6695, August 18, 1967.

31 Wkly. Comp. Presidential Docs., May 25, 1970.

${ }^{32}$ Crosby, supra, n. 2.

as Id.

34 Supra, n. 17.
} 
the boundary is the median line, every point of which is equidistant from the nearest points of the baselines from which the breadth of the territorial sea of each State is measured.

2. Where the same continental shelf is adjacent to the territories of two adjacent States, the boundary of the continental shelf shall be determined by agreement between them. In the absence of agreement, and unless another boundary line is justified by special circumstances, the boundary shall be determined by application of the principle of equidistance from the nearest points of the baselines from which the breadth of the territorial sea of each State is measured.

3. In delimiting the boundaries of the continental shelf, any lines which are drawn in

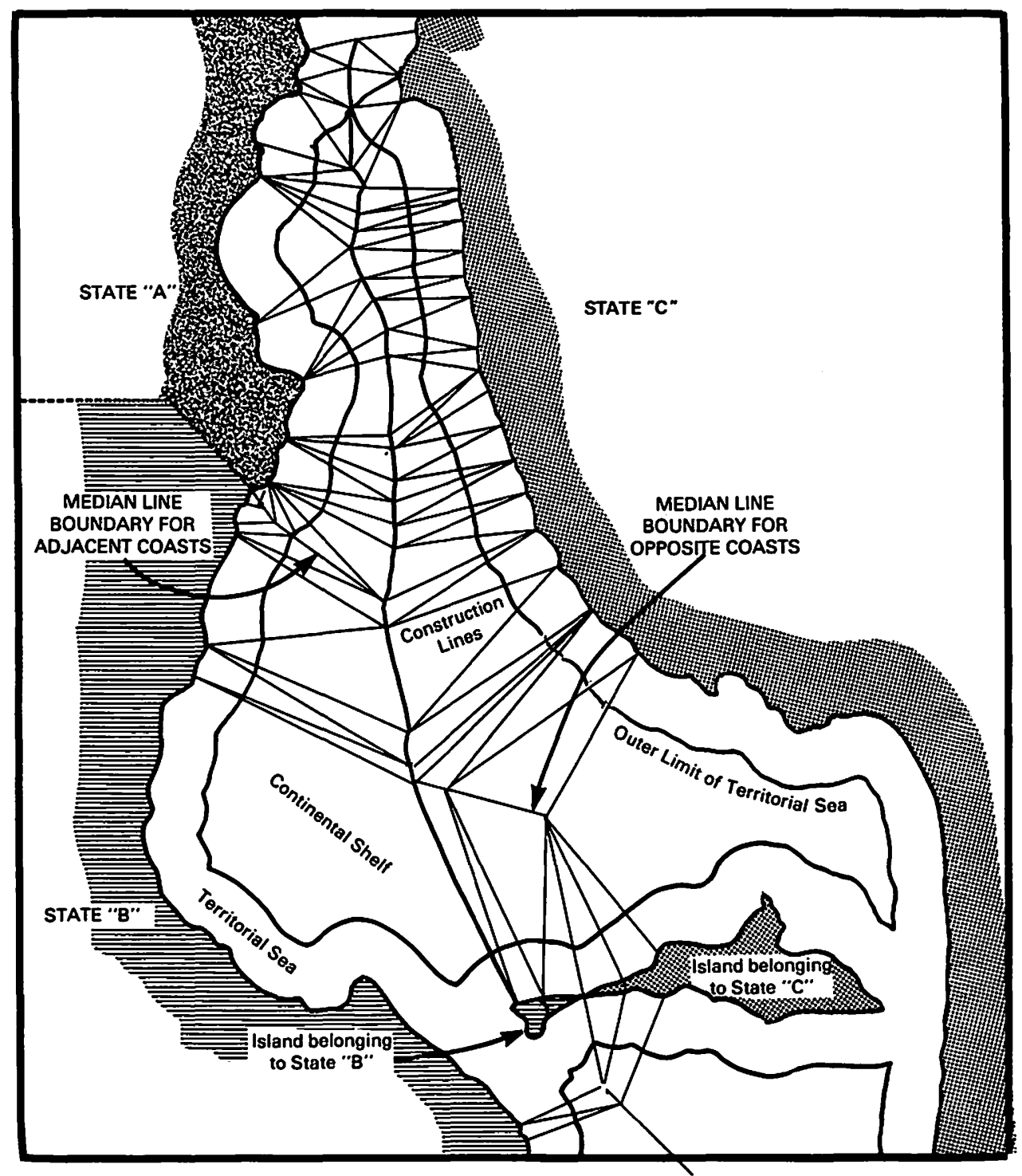


accordance with the principles set out in paragraphs 1 and 2 of this article should be defined with reference to charts and geographical features as they exist at a particular date, and reference should be made to fixed permanent identifiable points on the land.

The figure above clearly demonstrates the method of construction or demarcation of such boundaries. ${ }^{35}$

The procedures available to states for dividing up the continental shelf are, in order of preference; agreement, acceptance of the "principle of equidistance" adopted by article 6, or compulsory settlement by the International Court of Justice. To date there have been many international agreements based on the principle of equidistance-between Venezuela and Trinidad in the Gulf of Paria, ${ }^{36}$ between Saudi Arabia and Bahrain ${ }^{37}$ and Saudi Arabia and Iran ${ }^{38}$ in the Gulf of Persia, and between the U.K.I Norway/Denmark/Netherlands, and Norway/Denmark in the North Sea. Inasmuch as the Gulf of Paria agreement took place sixteen years before the 1958 convention and that Iran is the only country on the Gulf of Persia which is a signatory, it is evident that the median-line principle has a strong foundation in the body of customary law as well in convention.

Other principles have been applied, however, and it would be well to consider them as being an accepted part of customary law also. In the North Sea Continental Shelf Cases ${ }^{39}$ of 1969 the International Court of Justice held that article 6 did not constitute evidence of customary international law in a case involving the lateral boundaries of the continental shelf between West Germany and Denmark and West Germany and the Netherlands. In that case Germany argued that the delimitation of the continental shelf is governed by the "equitable principle" that each coastal state is entitled to a just and equitable share. Its ground for this argument was the "continental shelf principle" which stands on its own feet and need not be deduced from the Convention article, namely, that a state has an inherent or vested right to the continental shelf off its shores on the principle of appurtenance. ${ }^{40}$ The Court dismissed this submission, and also dismissed the submission of the Danes and the Dutch who claimed that the "equidistance-special circumstances" principle was mandatory by virtue of the 1958 convention.

The Court held that the equidistance technique was not an emerging principle of customary international law which crystalized in the Geneva Convention, nor had it become such a principle through subsequent state practice. The Court emphasized the fact that a continental shelf is a natural prolongation of the land area and gave the following rules to be followed by the parties to the case: ${ }^{41}$

Delimination is to be effected by agreement in accordance with equitable principles, and taking account of all the relevant circumstances, in such a way as to leave as much as possible to each Party all those parts of the continental shelf that constitute a natural prolongation of its land territory into and under the sea, without encroachment on the natural prolongation of the land territory of the other;

If, in the application of the preceding sub-paragraph, the delimitation leaves to the

is Krueger, The Background of the Doctrine of the Continental Shelf and the Outer Continental Shelf Lands Act, (1970) 10 Natural Resources Journal 460.

36 Treaty Relating to the Submarine Areas of the Gulf of Paria, February 26, 1942, U.N. Pub. Sales No. 1951, V. 2.

37 Signed February 22, 1958. See 7 Int'l. and Comp. L.Q. 519.

3月 Signed in Tehran, December, 1965.

39 [1969] I.C.J. 3.

10 President Truman's Proclamation of September 28, 1945, supra, n. 15.

1) [1969] I.C.J. 53. 
Parties areas that overlap, these are to be divided between them in agreed proportions or, failing agreement, equally, unless they decide on a regime of joint jurisdiction, user, or exploitation for the zones of overlap or any part of them.

In the course of the negotiations, the factors to be taken into account are to include:

the general configuration of the coasts of the Parties, as well as the presence of any special or unusual features;

so far as known or readily ascertainable, the physical and geological structure, and natural resources, of the continental shelf areas involved;

the element of a reasonable degree of proportionality, which a delimitation carried out in accordance with equitable principles ought to bring about between the extent of the continental shelf areas appertaining to the coastal State and the length of its coast measured in the general direction of the coastline, account being taken for this purpose of the effects, actual or prospective, or any other continental shelf delimitations between adjacent States in the same region (emphasis added).

The map below gives some idea of the complexities which were involved in dividing the continental shelf between the adjacent coastal nations in this case. 42

In spite of the North Sea Continental Shelf Cases it appears that article 6 of the Convention on the Continental shelf still contains widelyaccepted rules of international law. ${ }^{43}$ However, the Cases did point out that article 6 by itself is of limited value as a clear principle because of its reference to "special circumstances". West Germany pleaded "special circumstances" to obtain more favourable boundaries. This example demonstrates that such a plea could be made to rationalize a limitless number of circumstances so that the seemingly clear median-line principle is considerably weakened.

Additional problems arise if the two states do not use the same system of baselines from which the boundary is to be measured, or if there are islands off the coast of one or both of the states. In result, the convention is only a point of departure for negotiation.

\section{Present Boundary Questions}

Now that tapping of the oil and gas reserves of the continental shelf has become a practical reality, it is clear that boundary delimitations dividing the continental shelf in an equitable manner between coastal nations will have to be settled to the satisfaction of the parties concerned. Canada is currently faced with boundary questions in the following areas:

(a) Alaska/Canada boundary in the Beaufort Sea;

(b) Alaska/B.C. boundary in Dixon Entrance;

(c) U.S./Canada boundary of the Strait of Juan de Fuca;

(d) Maine/Nova Scotia boundary;

(e) France/Canada boundary around the Islands of St. Pierre and Miquelon;

(f) Greenland/Canada boundary in Davis Strait.

Needless to say, oil companies are going to shy away from these areas until they have some guarantee of security resulting from a fixed boundary delimitation. In addition these unsettled claims are causing problems in the regulation of coastal fisheries and in the regulation and control of shipping, traffic safety and marine pollution. The state of international law concerning responsibility for environmental damage to

42 [1969] I.C.J. 15.

43 Brownlie, Recommendations on the Limits of the Continental Shelf and Related Matters: A Commentary 145. Proceedings of the Fourth Annual Conference of the Law of the Sea Institute, June 23-26, 1969. The University of Rhode Island, Kingston, Rhode Island. 


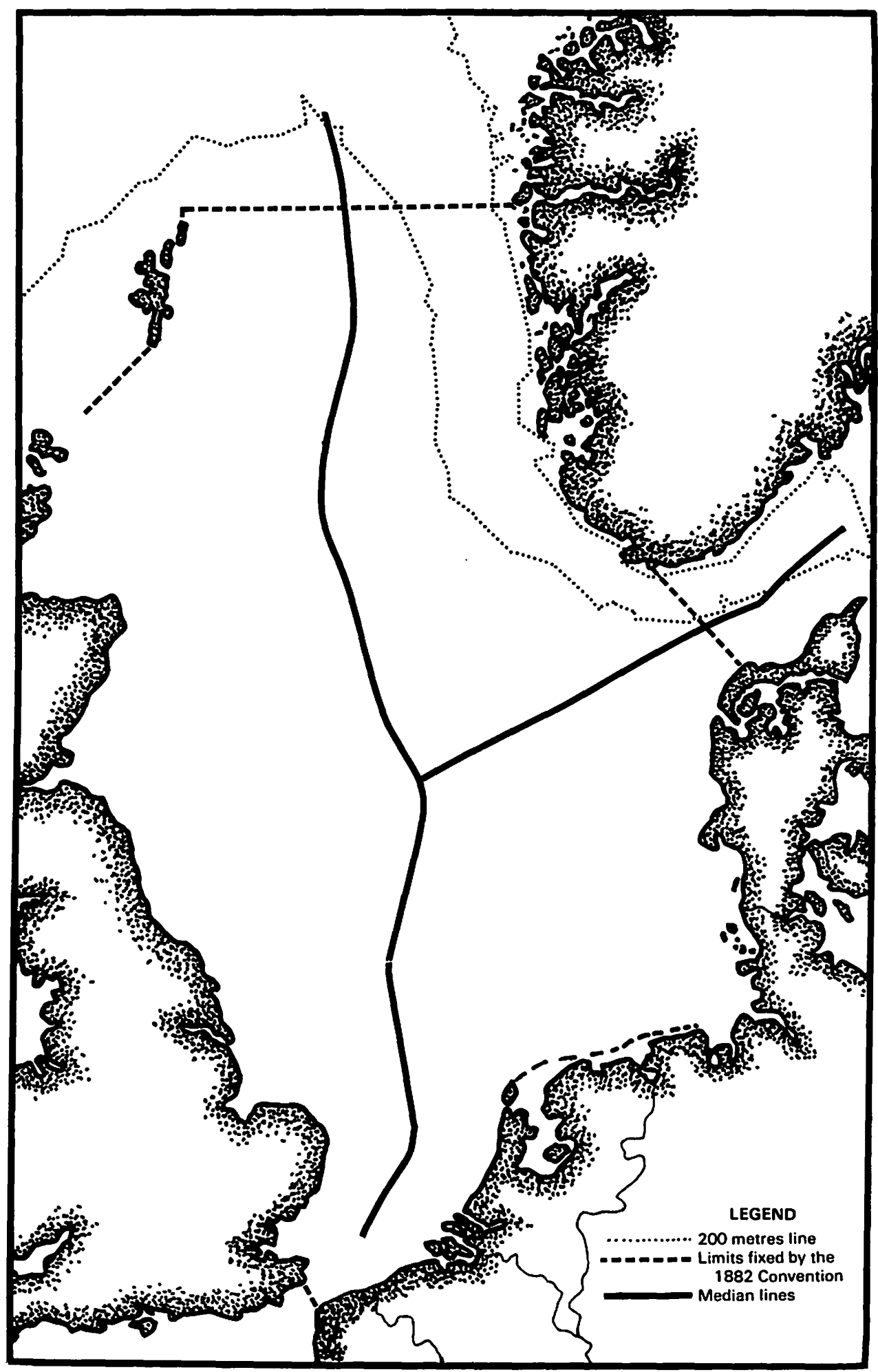


another state and the rights to compensation are already uncertain. A disaster such as an oil spill in one of these disputed areas would compound the uncertainty, defying any responsibility of an equitable settlement.

It should be noted that while Canada has adopted the system of straight baselines in accordance with the principles laid down by the decision in the Anglo-Norwegian Fisheries case ${ }^{44}$ and codified by the Geneva Convention, the United States adheres to the principle of the low-water mark following the sinuosities of the coast as the normal baseline. ${ }^{45}$

\section{(a) Alaska/Canada Boundary in the Beaufort Sea}

There has been much discussion as to how far north Canadian jurisdiction extends over the water, islands and seabed of the Arctic regions. Arguments for absolute Canadian sovereignty have been based on the sector principle, the straight baseline system, the doctrine of the continental shelf, and the principle of actual use and occupation. While the doctrine of the continental shelf provides a basis for extension of Canadian control of the resources of the seabed in a northward direction, what is yet undecided are the boundaries of the continental shelf to the east between Canada and Greenland, and to the west between Canada and Alaska.

The Alaska/Canada land boundary in the northern regions is settled along the 141st meridian of longitude. The first definition of that boundary was made by the Anglo-Russian treaty of 1825.46 In 1867 a convention between Russia and the United States ceded what is now Alaska to the latter, making the United States a party to the 1825 treaty. Then, by acquisition of Rupert's Land from the Hudson's Bay Company in 1869 and by entry of British Columbia into Confederation in 1871, Canada acquired an interest in the Alaskan boundary question. The 1825 treaty described the boundary on the Beaufort Sea as follows:47

... from this last mentioned point the line of demarcation shall follow the summit of the mountains situated parallel to the coast as far as the point of intersection of the 141st degree of west longitude; and finally from the said point of intersection, the said meridian line of the 141st degree in its prolongation as far as the Frozen Ocean, shall form the limit between the Russian and British possessions on the continent of America to the Northwest (emphasis added).

After acquisition of Alaska by the United States there was much argument as to the boundary of the Alaska Panhandle region, ${ }^{48}$ but the 141st meridian was accepted by all parties concerned as the eastward limits of United States territory and when the Yukon Territory was created in $1898^{49}$ the western boundary in the north of this new entity was described as: ${ }^{80}$

Beginning at the intersection of the 141st meridian of west longitude from Greenwich with a point on the coast of the Arctic Sea, which is approximately $69^{\circ} 39^{\prime}$, and named on the Admiralty Charts, "Demarcation Point"; thence due south on said meridian

\footnotetext{
4 [1951] 1.C.J. Vols. I-IV.

45 Krueger, An Evaluation of United States Oceans Policy, (1971) 17 McGill Law Journal 655.

${ }^{66}$ Convention Between Great Britain and Russia, signed at St. Petersburg, February 28/10, 1825.

47. Id. article III.

4s Munro, The Alaska Boundary Dispute (1970).

49 Yukon Territory Act, S.C. 1898 , c. 6.

so Id. schedule.
} 
(which is also the boundary line between Canada and Alaska) for a distance . . . (emphasis added).

The existing boundary was settled by the Alaska Boundary Tribunal set up by a convention between the United States and Great Britain in 1903, which rendered its award in the same year. Throughout the hearings it was clear that the 141st meridian was accepted by all as the westward limit of Alaska and the wording of the Anglo-Russian agreement of 1825 , i.e. "as far as the Frozen Ocean", gave rise to no dispute with respect to the northward extension of this line. ${ }^{51}$

In 1906 an International Boundary Commission was established between Great Britain and the United States to survey and map the 141st meridian, ${ }^{52}$ and the survey stopped at the coastline. ${ }^{53}$ The offshore boundary has never been settled.

An extension of the 141st meridian to divide the continental shelf in the Beaufort Sea could be argued to result in an inequitable distribution to the United States because it would not conform with the equidistant principle. Although there appears to have been no bilateral discussion

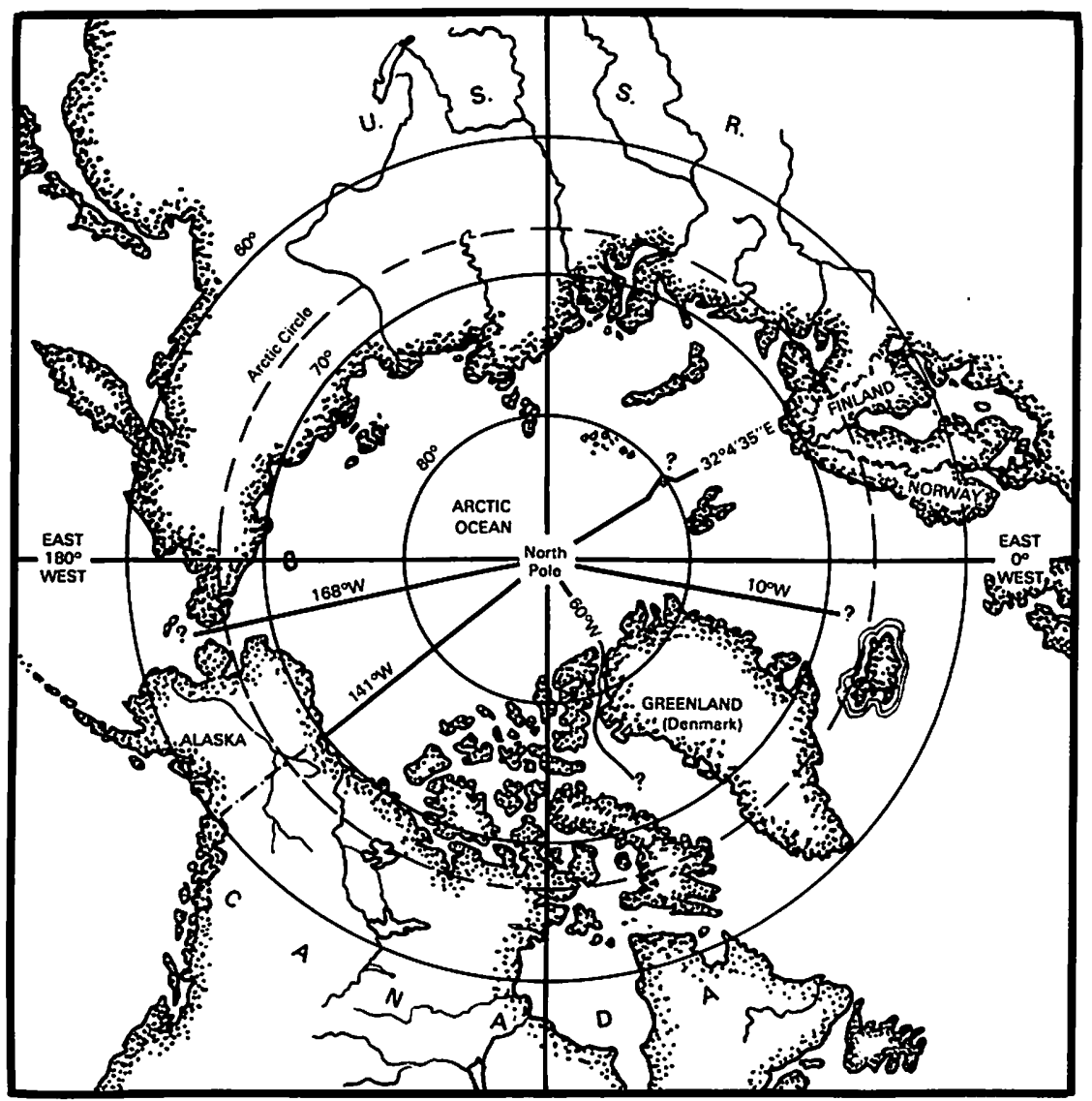

51 Proceedings of the Alaskan Boundary Tribunal, Vol. I, 30(5). Decision of the Tribunal, October $20,1963$.

52 Convention Between the United Kingdom and the United States of America Respecting the Boundary Between the Dominion of Canada and Alaska, Signed at Washington, April 21, 1906.

s3 Sixth Joint Report of the Commissioners for the Demarcation of the Meridian of the 141st degree of West Longitude, Washington, December 12, 1912. 
on the division of the shelf in the Beaufort Sea, Canada apparently regards the 141st meridian as defining the limits of offshore national jurisdiction. For example when the sector principle for division of Arctic regions was considered to be a tenable argument, an order-in-councilis established a provisional sector in 1897, delimiting an area between the 141st meridian on the west, and the 60th meridian on the east, and in 1904 maps were issued showing these sector lines. ${ }^{55}$ The map above shows the resulting sector. ${ }^{56}$

More recently, the Arctic Waters Pollution Prevention Act57 establishes pollution control jurisdiction over an offshore area bounded on the west by the 141st meridian of longitude. In addition the 1969 Hydrographic Survey indicates activity following diligently the 141st meridian as the western extreme of Canadian jurisdiction. ${ }^{58}$

A glance at the Arctic coastline bordering Alaska and the Yukon Territory will show that application of the median line principle based on the sinuosities of the coast or on straight baselines would result in an equidistant line much less favourable to Canada. The diagram below is intended to show in rough form where a median line would run if drawn from the intersection of the 141st meridian and the coastline. Inasmuch as the diagram was drawn by lawyers with little manual dexterity and even less mathematical instinct, we disclaim any pretense to accuracy:

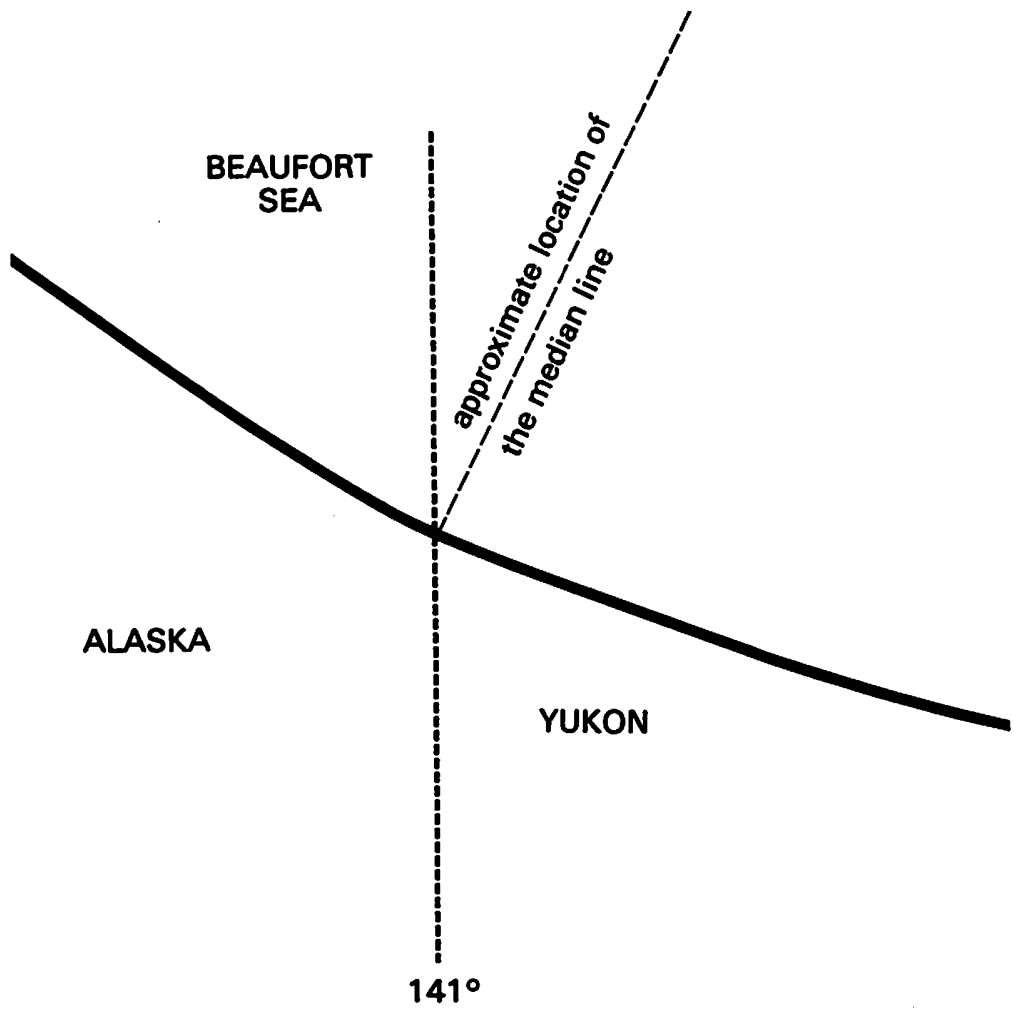

is S.O.R./97-3388.

5s MacDonald, ed., The Arctic Frontier 215 (1966).

so Id. at 219.

37 Supra, n. 14.

so Stewart and Dickie, Ad Mare: Canada Looks to the Sea 87 (1971). 
This median-line claim is clearly available to the United States. The probability of the United States taking such a stand is not remote in light of the acknowledged petroleum potential of the region.

(b) Alaska/B.C. Boundary in Dixon Entrance

Canada contends that the matter was settled in 1903 by the Alaska Boundary Tribunal which gave the Alaska Panhandle to the U.S. and then drew a demarcation line westward straight out to sea through Dixon Entrance. Canada's position is that this line is also the B.C./Alaska sea boundary. The U.S. takes the position however, that the tribunal only settled the land boundary, not the sea boundary. ${ }^{59}$ At the moment the area is not of too great concern to the oil industry but it is of major concern to the fishing industry. Because a settlement as to fisheries could include jurisdiction over the ocean bottom as well, the issue should be closely watched by the oil industry.

(c) U.S./Canada Boundary at Mouth of the Strait of Juan de Fuca

The boundary of the continental shelf at the mouth of the Strait of Juan de Fuca has never been determined. Again, as with the B.C./Alaska border on the Pacific, there is no current push for such settlement by the oil industry but there are other incentives to reach a satisfactory boundary agreement on the shelf. The Treaty of Washington in 1846 settles the land boundary along the 49th parallel and the water boundary in the Gulf of Georgia by simply stating that the boundary line along the 49th parallel should run:

.. . to the middle of the channel which separates the continent from Vancouver's Island; and thence southerly through the middle of said channel, and of Fuca's Straits to the Pacific Ocean.

A look at the map following at 444 will show that there are several possible solutions: the matter clearly will have to be settled by agreement.

\section{(d) Maine/Nova Scotia Boundary}

This is one of the thorniest boundary questions at the moment because of the high oil and gas potential. In this area the United States favours a boundary that follows the geologic feature of the continental shelf under the "equitable principle" concept of the North Sea Continental Shelf Cases, while Canada is arguing for the median-line principle of the Geneva Convention. ${ }^{60}$ The current issue involves specifically the northeast portion of Georges Bank in the Gulf of Maine lying between Nova Scotia and Massachusetts. Canada has gone so far as to issue exploration permits in the area, but the United States has served public notice to industry that it does not recognize the validity of these permits or of Canada's claim to sovereignty in that part of the continental shelf.61 The map following at 444 shows the area in dispute. ${ }^{62}$

(e) France/Canada Boundary Around St. Pierre and Miquelon

The islands of St. Pierre and Miquelon lie, at their closest point, 14 nautical miles south of Newfoundland, but the Canadian island known as Little Green Island lies only three miles from the French coastline. Canada's view is that a median line should be drawn between Little

\footnotetext{
s9 U.S.Canada Disputes: Our Boundaries Not So Peaceful, Vancouver Sun, September 27, 1971, at 13.

so Krueger, supra, n. 35 at 46.

61 Canada and U.S. to begin talks on Outer Shelf Boundaries, Oil and Gas Journal, March 23, 1970, at 26.

62 Id. at 27 .
} 

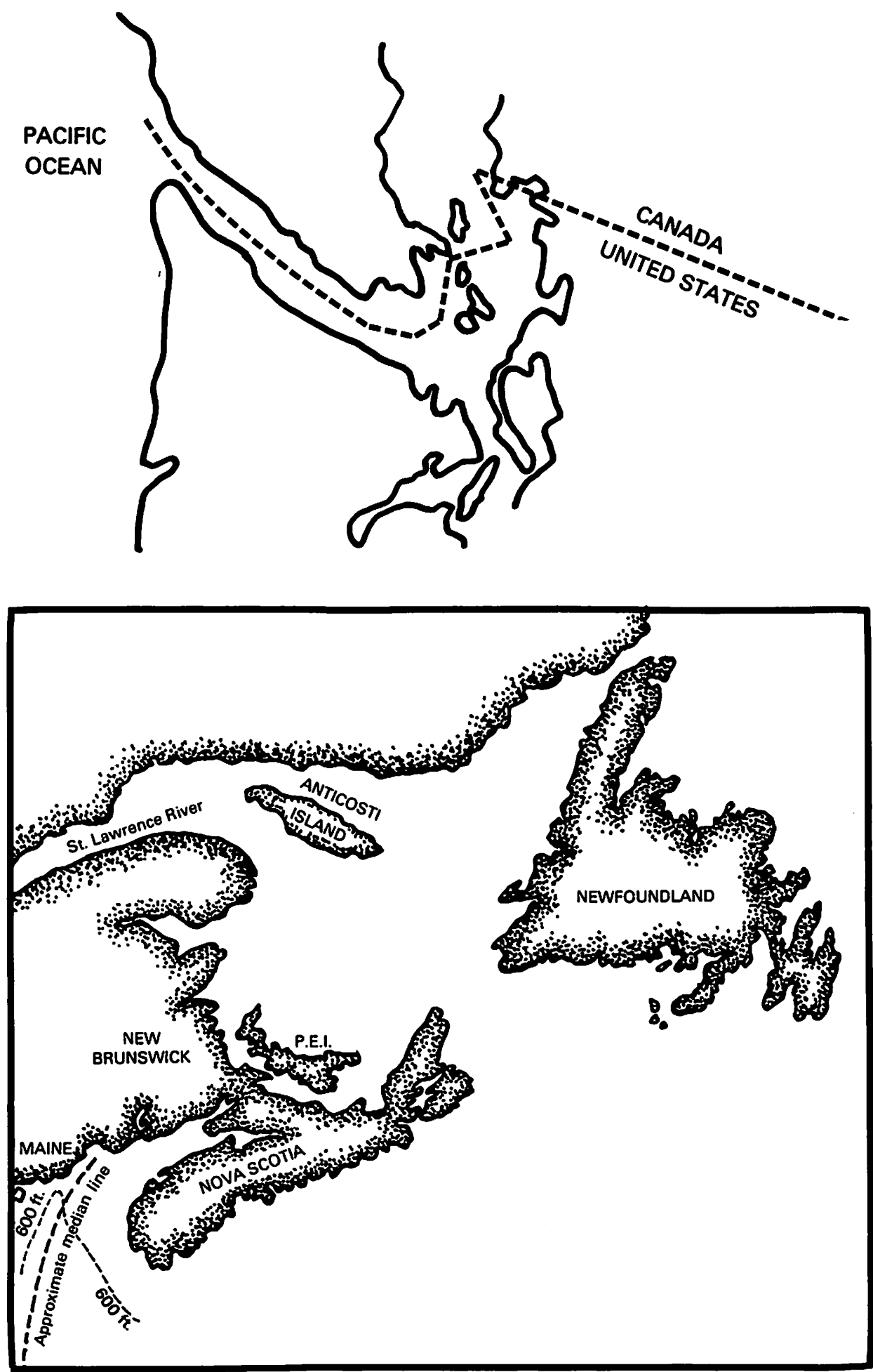
Green and St. Pierre, which would put the boundary $11 \frac{1}{2}$ miles from the French coast. The French have argued that the boundary should be midchannel between their islands and the Burin Peninsula which would give no territorial sea at all to Green Island. ${ }^{63}$ The map below, and the following map at 446 , give a clearer picture of the issues involved. ${ }^{64}$

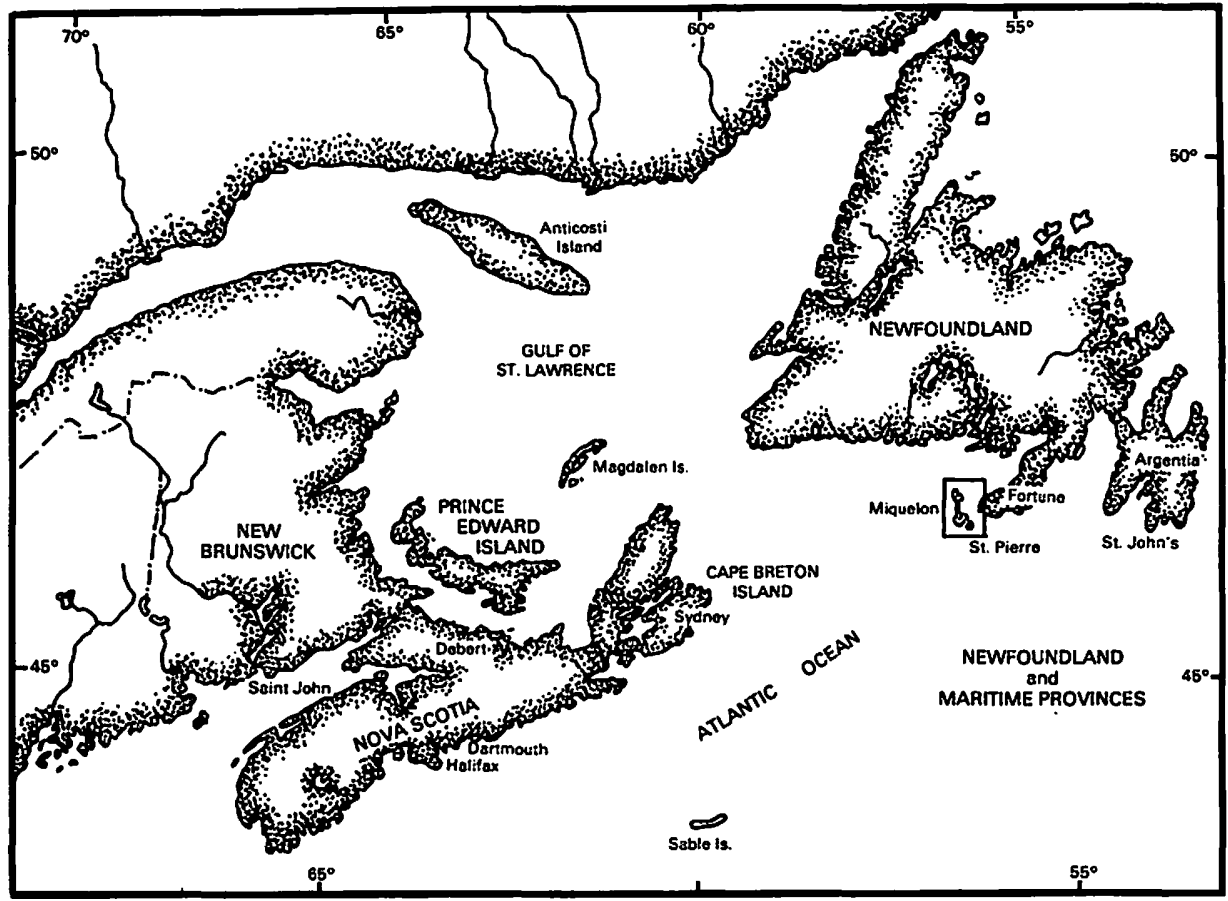

The islands were ceded to France by Britain by the Treaty of Paris in 1763 and the Canadian government is of the opinion that Canada should have a chance to renegotiate the terms inasmuch as they were agreed upon by two other countries.

The islands are less than 10 miles by 10 miles and are inhabited by about 5,000 people who "fish, fur-farm and supply Newfoundland smugglers with liquor and French wares". 65 On this basis of sovereignty, 


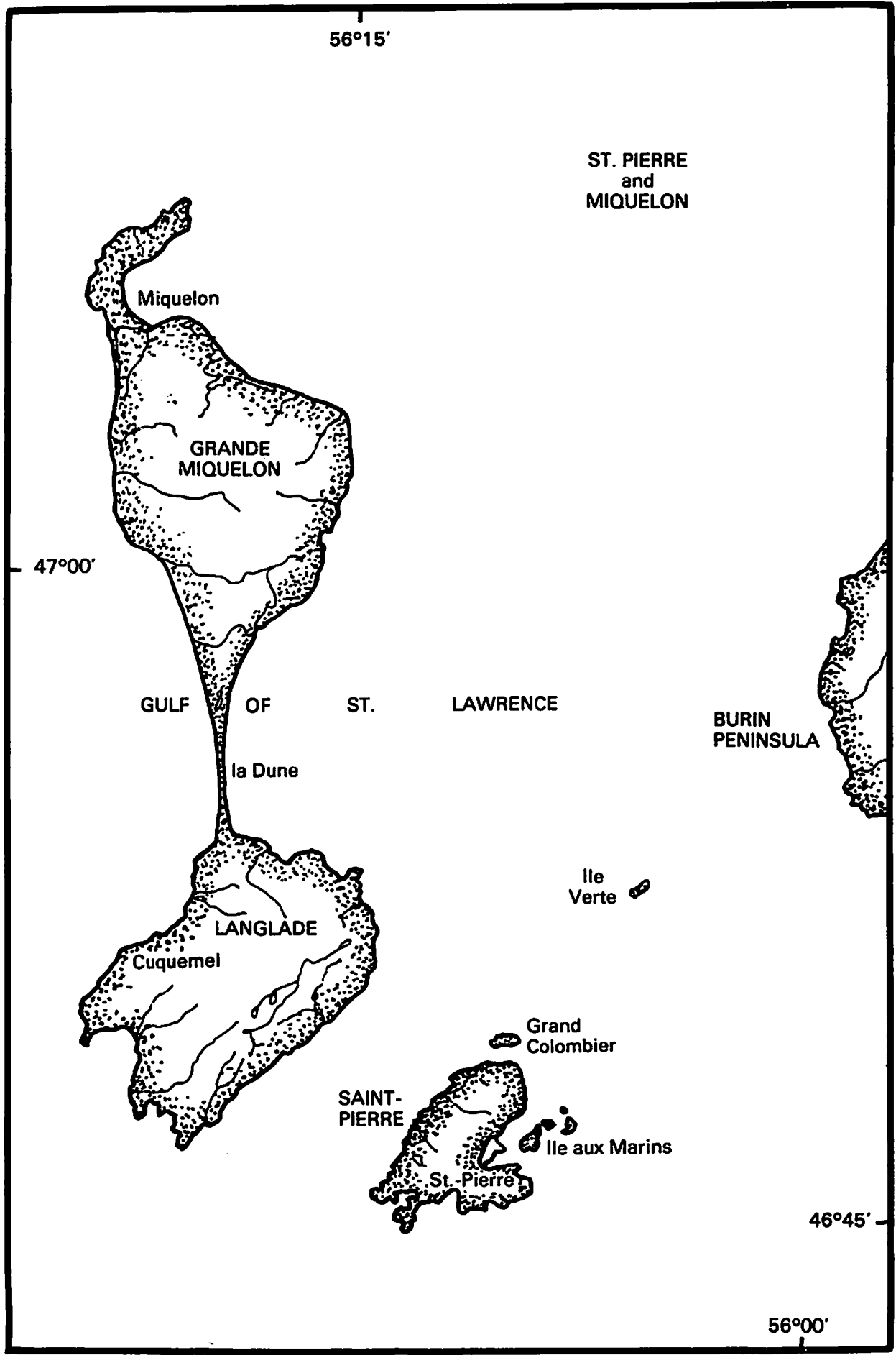

a.1 [1970] 1 International Canada at 86

Bt Anglin, The St. Pierre and Miquelon Affair of 1941 (1966). 
France is claiming ownership of the mineral resources of about 20,000 square miles of continental shelf. In fact France can base its claim in international law under the Geneva Convention of 1958 which by article 6 established the doctrine of "equidistance" for the determination of boundaries between the continental shelves of opposite and adjacent countries.

Under this doctrine France claims offshore oil, gas and mineral rights from the islands halfway (median-line) to the nearest parts of Canada on three sides, and southward more than 200 miles to the outer edge of the continental shelf.

Because this large area is so out of proportion to the size of the French colony compared to Canada, Canada is taking the position that "special circumstances" (mentioned in the Geneva Convention) justify another boundary delimitation which would give a smaller area to France. 66

In 1967 France issued an oil exploration permit covering the islands and adjacent waters to Petropar (now Elf Oil), a company in which the French government has a large interest. ${ }^{67}$ In 1968 the French government passed a law regulating and proclaiming sovereign rights over the exploration for, and exploitation of, natural resources of the continental shelf adjacent to French territory, specifically including overseas French territories. ${ }^{68}$ In the same year, Ottawa retaliated by issuing permits to Gulf Oil and Mobil Oil which overlap the French permit. Since that time there has been no accord in negotiations. It is apparent neither side wants to go to the International Court of Justice as both have telling arguments. Needless to say, other matters such as agreements on fishing rights, and responsibility for pollution will be dependent as well, on the outcome of these negotiations.

There has recently been an agreement regarding fisheries between France and Canada in the area between the French islands and Newfoundland. ${ }^{69}$ The agreement is simply a convenient arrangement to take care of the fishery problems for now, and has not settled the question of ownership of the continental shelf resources. It provides that:70

No provision of the present agreement shall be interpreted as prejudicing the views and future claims of either party concerning internal waters, territorial waters, or jurisdiction with respect to fisheries or the resources of the continental shelf, or the bilateral or multilateral agreements to which either government is a party.

(f) Greenland/Canada Boundary in Davis Strait

Official Canadian maps show the international boundary between Canada and Greenland as lying near the middle of Davis Strait, Baffin Bay and the other waters separating the two land masses northward to the Arctic sea. The status of the waters and seabed of the Davis Strait and Baffin Bay is still uncertain. The line which the Canadian government has always appeared to recognize as the eastern boundary to territorial claims running along the 60th meridian from the North Pole, has not been clearly defined from the point at which it enters the narrow passage separating Ellesmere Island and Greenland. To the date of this paper there has apparently been no agreement between Canada and Denmark

\footnotetext{
66 House of Commons Debates, March 27, 1972, at 1161.

6: Supra, n. 65.

68 Loi No. 68-1187 du Décembre 1968.

69 Agreement between Canada and France on their Mutual Fishing Relations, Ottawa, March 27, 1972.

to Id. article 9.
} 
as to where this boundary should lie. As recently as 1971 there has been a dispute over a small island known as Hans Island which lies in the passage between Greenland and Ellesmere Island. ${ }^{71}$

\section{Conclusions Re International Boundaries}

None of the outer continental shelf boundaries between Canada and its opposite and adjacent coastal states has been settled. It is only since the continental shelf has become exploitable that the need to agree on a fixed delimitation of jurisdictions has arisen. Likely the first boundaries to be settled will be those in the areas of known or potential oil and gas reserves but the problems involved in deciding each of the boundaries are similar, and all the principles now recognized by the international community will have to be considered for each area.

The guidelines laid down by the International Court of Justice in the North Sea Continental Shelf Cases proved inadequate and the countries involved in those cases have now settled on an approach based on the physical and geological configuration of the shelf itself. ${ }^{72}$ This approach, the equidistance principle of the Geneva Convention and an appeal to what is "equitable" appear to be the tenable arguments, not to mention trade-offs between different areas. Canada, like most countries, finds its advantage served in some cases by one approach and in other cases by another. In the case of Nova Scotia and Maine the equidistance principle is clearly to Canada's advantage, while on the Alaska-Yukon boundary and in the case of St. Pierre and Miquelon, Canada is favoured by asserting "special circumstances" based on what is "equitable". It will require skilful negotiating to secure satisfactory solutions in all these boundary cases.

\section{DOMESTIC ISSUES IN A FEDERAL CONTEXT}

From a legal point of view, the sovereign rights over the seabed resources accruing to Canada under international law must be received and allocated either to federal or provincial jurisdictions or to both according to domestic constitutional law notwithstanding that this legal framework was not designed for such a task or that such allocation, far from being an abstract legal question, affects the basic political fabric of Canadian society-so much so that the former Premier Jean Lesage of Quebec declared that the province would not recognize any court decision on the question of ownership of seabed resources.

We will not attempt a review of the legal ingredients involved in reaching a domestic legal solution to the questions of ownership and jurisdiction respecting Canadian seabed resources other than to classify them as historical, such as early statutes, maps, colonial office documents, etc., and formal, such as treaties, colonial charters, and particularly the distributive provisions of the British North America Act, 1867. In addition, since the legal recognition of a nation's rights over seabed resources derives from international law, a final ingredient is what the domestic law may say about the enjoyment of rights and the discharge of responsibilities within the international community. All these classes of legal materials were considered by the court in the Offshore Minerals Reference. ${ }^{73}$

\footnotetext{
"' Vancouver Sun, July 16, 1971.

:2 Talks Aduance on Disputed North Sea Boundaries, Oil and Gas Journal, March 1970, at 108.

${ }^{73}$ [1967] S.C.R. 792, 65 D.L.R. 353.
} 
Rather, we will examine what the Offshore Minerals Reference did and did not decide. Then we will review for comparative purposes the settlements that have been reached in similar disputes in Australia and the United States. Next, we will analyze the proposals which the federal government has made to the provinces for settling the offshore minerals dispute; and, finally, we will outline several alternative solutions that might ultimately provide a Canadian settlement.

\section{What the Offshore Minerals Reference Did and Did Not Decide}

With respect to the seabed resources of the territorial sea, the Offshore Minerals Reference says (i) that they are the property of Canada, (ii) that Canada has the right to explore and exploit them and (iii) that they are subject to the legislative jurisdiction of Canada. With respect to the seabed resources of the continental shelf beyond the territorial sea, the case says (i) that Canada has the right to explore and exploit them and (ii) that they are subject to the legislative jurisdiction of Canada. These pronouncements were made as an advisory opinion given under the reference procedure whereby the Supreme Court of Canada may be called on to give its opinion on abstract constitutional questions. The reference in this case confined the issues to those concerning the Province of British Columbia but the opinion of the Court indicates that the British Columbia issues are no different from those applying in the other offshore regions of Canada save insofar as another coastal province might demonstrate a different constitutional evolution respecting its boundaries. In particular, it would have to show that in a formal way the provincial boundary has, at some time in the past, been extended beyond the lowwater mark to include water-covered areas.

The Court's opinion may be summarized as follows:

1. In 1871 when it entered Confederation, the Province of British Columbia did not have ownership or property in the territorial sea and the Province has not since then acquired such ownership or property.

2. It is Canada which is recognized by international law as having rights in the territorial sea adjacent to the Province of British Columbia. Canada has now full constitutional capacity to acquire new areas of territory and new jurisdictional rights which may be available under international law. The effect of the Territorial Sea and Fishing Zones Act of 1964 and of the Geneva Convention on the Territorial Sea and the Contiguous Zone of 1958 is that Canada is recognized in international law as having sovereignty over a territorial sea three nautical miles wide. It is part of the territory of Canada. Canada has property in the bed of this territorial sea and the right to explore and exploit its resources. Canada also has exclusive legislative jurisdiction in respect of them either under s. 91(1A) of the B.N.A. Act or under the residual power in s. 91. Since the bed of the territorial sea is not within the province, such legislative jurisdiction does not fall within any of the enumerated heads of s. 92. Further, the mineral resources of this seabed are of concern to Canada as a whole and go beyond local or provincial concern or interests.

3. With respect to both the territorial sea and the continental shelf beyond, since Canada is the sovereign state recognized by international law and will have to enter into arrangements with other 
states respecting rights to exploit resources and will have to answer the claims of other states for any breach of obligations and responsibilities imposed by international law, it is Canada that has the right to exploit and the legislative jurisdiction over the seabed resources.

These reasons might be summed up very shortly by saying that the territory of British Columbia stops at the low-water mark, that legislative jurisdiction does not fall under any of the heads of s. 92 of the B.N.A. Act but is included within the "peace, order and good government" and the residuary provisions of $\mathrm{s}$. 91 , and that because the rights to the seabed resources are derived from international law, they belong to Canada.

One noted authority in international law who is quoted by the Supreme Court of Canada in the Offshore Minerals Reference has since characterized the Court's opinion as a "clear, legalistic approach . . . untrammelled by historical hypothesis". ${ }^{74}$ This writer speaks of the difficulty of adapting newly emerging rights under international law into a federal system in the following way: ${ }^{75}$

It now becomes clear that we are confronted with a murky legal history, much confused thinking and too much casual research into the antecedents of the problem. The judiciary which is now called upon to make findings of law has not grappled happily with the intertwined strands of precedent, histcry, political philosophy, and local and international issues which make up the problem, and it cannot be expected to do so without better guidance through this labryinth of source material than has hitherto been provided by legal investigation. If bad history tends to make bad law, in a federal system where vast sociological issues are at stake, too much frozen precedent may compound the evil.

The reasoning of the opinion in the Offshore Minerals Reference leads to speculation that only in the case of the Province of Newfoundland is it likely that different answers would be given to the questions before the court. This possibility results because Newfoundland may be able to show that its boundaries extended beyond low-water mark to include the territorial sea at the time it entered Confederation in 1949. The other maritime Canadian provinces all entered Confederation prior to the period between 1919 and 1932 when Canada gained status as an independent sovereign state recognized in international law. The opinion of the Court was that prior to that period any jurisdiction over the territorial sea had to be asserted by the United Kingdom and was not a right of the colony.

It may be more rewarding to analyze the Offshore Minerals Reference in terms of what it did not decide.

First, because it was a reference, the opinion of the Court was advisory only, and therefore is not a precedent binding in the technical sense. Also, the reference related only to the Province of British Columbia and therefore the opinion should not be taken as conclusive with respect to other maritime provinces until one has made a complete review of the historical and formal material to ascertain what boundary pronouncements there may have been. In this respect it is worth noting that the official position of the other maritime provinces is that

' O'Connell, The Federal Problem Concerning the Maritime Domain in Commonwealth Countries, 1 Journal of Maritime Law and Commerce 389 at 401.

73 Id. at 395. 
the advisory opinion has not decided the questions as they relate to these other provinces.

The next item to note is that the terms of reference identified the seabed resources that were in question as being those "outside the harbours, bays, estuaries and other similar inland waters" of British Columbia. It is far from clear what areas are included within these words. For example, the government of British Columbia asserts that the Strait of Georgia comprises inland waters and that the seabed resources under the Strait belong to British Columbia whereas the federal government takes the position that these resources belong to the federal government under the Offshore Minerals Reference. This uncertainty about what comprises "harbours, bays, estuaries and other similar inland waters" is given as a reason by the Prime Minister of Canada for establishing arbitrary resource administration lines well within the federal territorial sea as the basis for dividing jurisdiction between Canada and the provinces. ${ }^{76}$

The case does not decide the status of Sable Island. This island belonged to Nova Scotia prior to Confederation, having long historical ties that knit it into the Nova Scotian social and political fabric. It became part of the property of Canada under the third schedule to s. 108 of the B.N.A. Act. Item 3 of this schedule enumerated "lighthouses and piers and Sable Island". A similar enumeration, also including Sable Island, appears in s. 91(9) of the B.N.A. Act whereby legislative jurisdiction is given to the Parliament of Canada. A strong case can be made for the view that the property and legislative jurisdiction which Canada acquired with respect to Sable Island was for navigational purposes only just as in the case of public harbours. It has been suggested in a dictum of Hunter C.J. in A.-G. for B.C. v. C.P.R., ${ }^{77}$ that the subsoil of the harbour vested in Canada by the B.N.A. Act extends only so far as necessary for harbour purposes with the underlying mines and minerals belonging to the province.

\section{The United States Experience}

The United States has already faced constitutional problems similar to those presently encountered in Canada. The method chosen to resolve these problems, initially at least, was to resort to the Supreme Court. The United States experience illustrates very well the complexity of the problems, and the length of time that may be needed to resolve them by legal proceedings. ${ }^{78}$

On October 19, 1945, the United States Attorney-General filed suit in the Supreme Court against the State of California, seeking a declaration that the United States possessed "paramount rights" over the lands lying seaward of the ordinary low-water mark for a distance of three nautical miles. In a decision handed down on January 23, 1947, the Supreme Court upheld that United States claim. ${ }^{79}$ Similar rulings followed in 1950 , in suits involving Louisiana and Texas. ${ }^{80}$ However, Congress then intervened, and with the Submerged Lands Act of 1953,81

\footnotetext{
it Official statement by the Prime Minister, December 2, 1968.

$\because$ (1905) 1 W.W.R. 299.

${ }_{78}$ A detailed review of the United States litigation may be found in Krueger, supra, n. 16.

79 U.S. v. California (1947) 332 U.S. 19.

so U.S. v. Louisiana (1950) 339 U.S. 699; U.S. v. Texas (1950) 339 U.S. 707.

$\$ 167$ Stat. 29; U.S.C. ss. 1301-15 (1953).
} 
granted the coastal states title to the submerged lands seaward from their coasts to a distance of three geographical miles, and up to three marine leagues in the Gulf of Mexico where special circumstances could be shown. Congress also enacted the Outer Continental Shelf Lands Act of $1953,{ }^{82}$ to provide a system for oil and gas leasing in federal offshore areas, and to apply a comprehensive system of law to operations conducted in such areas. These statutes, however, did not end the controversy. The constitutionality of the Submerged Lands Act was challenged in the Supreme Court, without success. ${ }^{83}$ Next, the Court was called upon to decide the seaward boundaries of the coastal states' jurisdiction in the Gulf of Mexico. ${ }^{84}$ Then there arose the most complex issue of determination of the coast line from which the limits of jurisdiction of the coastal states was to be measured; despite decisions upon this question by the Supreme Court in $1965^{85}$ and $1969,{ }^{86}$ this issue has not yet been finally resolved. Most recently, an action has been instituted in the Supreme Court to settle the question of federal-state rights over submerged lands on the east coast of the United States, ${ }^{87}$ and a further action is awaiting determination in the federal District Court for the District of Alaska, involving federal-state rights to submerged lands in Cook Inlet. ${ }^{88}$

\section{The Australian Experience}

Offshore exploration for oil and gas was of little importance in Australia until 1960, when the Broken Hill Proprietary Company Limited (BHP), through its subsidiary Hematite Exploration Pty. Ltd., took up offshore permits from the South Australian, Tasmanian and Victorian Governments, extending over an area of approximately 66,000 square miles. ${ }^{89}$ This raised the issue of jurisdiction over offshore areas, and in June 1962 the first of several meetings was held between the Commonwealth Minister for National Development and the State Ministers for Mines, to discuss offshore oil and mineral rights. ${ }^{90}$ Preliminary discussions only were held at this meeting, pending examination of the constitutional questions involved by the Commonwealth and States' Attorneys-General. ${ }^{91}$ The second Ministerial meeting was held in January 1964, and by this time the States had decided that they should control offshore oil and mineral rights but that conflict with the Commonwealth over this issue should be avoided "at any cost". 92

On April 17, 1964, the Commonwealth Minister for National Development and the State Ministers for Mines met once again, this time with their respective Attorneys-General. ${ }^{93} \mathrm{By}$ this time interest in offshore oil and gas exploration had reached a peak, with the announcement by BHP that Esso Exploration Australia Inc. (Esso) would join

\footnotetext{
8267 Stat. 462; 43 U.S.C. s8. 1331-43 (1953).

${ }^{83}$ Alabama v. Texas et al, and Rhode Island v. Louisiana et al. (1954) 347 U.S. 272.

st U.S. v. Louisiana et al. (1959) 363 U.S. 1; U.S. v. Florida et al. (1959) 363 U.S. 121.

es U.S. v. California (1965) 381 U.S. 139.

*6.S. v. Louisiana et al. (Texas Boundary Case) (1969) 394 U.S. 1; U.S. v. Louisiana et al. (Louisiana Boundary Case) (1969) 394 U.S. 11.

87 U.S. v. Maine et al. No. 35, Original.

at U.S. v. Alaska No. A-45-67.

*9 Report from the Senate Select Committee on Off-Shore Petroleum Resources (1971) at 3.26.

90 Id. at 4.4.

91 Id.

92 Livermore, Evidence, May 3, 1968; Id. at 4.6.

${ }^{93}$ Id. at 4.7.
} 
that company in its offshore operations. ${ }^{94}$ At this meeting it was recognized that both the Commonwealth and the States were anxious to avoid litigation as the means for resolving their conflicting constitutional claims in relation to offshore areas. Accordingly, an agreement was reached that a national solution to the problem of offshore oil and gas exploration and exploitation was necessary. The Ministers resolved that without prejudice to the constitutional claims of the Commonwealth and the States, there should be an agreement upon joint arrangements over the whole offshore seabed in relation to exploration for and exploitation of oil and gas, but that this should not be taken as a precedent for solving problems of other resources in these areas. ${ }^{95}$

Negotiations to settle the terms of this agreement took a further three years, these being concluded at a Ministers' meeting on April 7, $1967 .{ }^{96}$ In the meantime both oil and gas had been discovered by EssoBHP in the Gippsland Shelf region offshore from Victoria, and the pressure to issue production titles in respect of these discoveries with the least possible delay was an important factor encouraging finalization of the negotiations. ${ }^{97}$

The Agreement ${ }^{98}$ was executed by the Commonwealth and the six States on October 16, 1967.

The main features of the Agreement are that the Governments which are parties to it undertake to legislate with respect to all offshore oil and gas operations in identical terms, ${ }^{99}$ and further undertake not to amend the legislation so enacted unless all Governments agree to the amendment. ${ }^{100}$ Moreover, the Governments undertake not to make, amend or repeal regulations under the legislation except in accordance with an agreement between them. ${ }^{101}$

The result has been described as "mirror" legislation. ${ }^{102}$ The entire Australian territorial seabed and continental shelf are divided into "Adjacent Areas", one appertaining to each state and coastal territory. The Commonwealth legislation is applicable to all Adjacent Areas, whereas each State statute applies only to the particular Adjacent Area, lying offshore from its coast. The boundaries of all the Adjacent Areas are defined in the Second Schedule to the principal Commonwealth Act, and the Second Schedule to each State statute contains a definition of that state's area. The seaward boundaries are defined in relation to points of stated latitude and longitude, whereas the landward boundary in each case is the coastline at mean low water. However, these boundaries are subject to the overriding provision that the Adjacent Areas

9" Id. at 3.27.

9s Id. at 4.7 .

96 Id. at 4.22 .

9: Id. at 4.16.

9x Agreement relating to the Exploration for, and the Exploitation of, the Petroleum Resources, and certain other Resources, of the Continental Shelf of Australia and of certain Territories of the Commonwealth and of other Submerged Land.

or Id. at clauses $3,4$.

$100 \mathrm{Id}$. at clause 6.

101 Id. at clause ?.

102 Legislation enacted by the Commonwealth Parliament pursuant to the Agreement is: Petroleum (Submerged Lands) Act 1967, No. 118 of 1967, amended by the Petroleum (Submerged Lands) Act 1968, No. 1 of 1968; Petroleum (Submerged Lands) (Royalty) Act 1967, No. 119 of 1967: Petroleum (Submerged Lands) (Exploration Permit Fees) Act 1967, No. 120 of 1967; Petroleum (Submerged Lands) (Production Licence Fees) Act 1967, No. 121 of 1967; Petroleum (Submerged Lands) (Pipeline Licence Fees) Act 1967, No. 122 of 1967; Petroleum (Submerged Lands) (Registration Fees) Act 1967, No. 123 of 1967; Petroleum (Ashmore and Cartier Islands) Act 1967, No. 124 of 1967. An example of State legislation is the Victorian statute, Petroleum (Submerged Lands) Act 1967, No. 7591. 
extend only to (a) areas of territorial waters and (b) areas of superjacent waters of the continental shelf. This has two results. Firstly, internal waters as recognized by international law are not included; and secondly, the seaward boundaries of the Adjacent Areas are in fact determined by the international law definition of the limits of national jurisdiction over the continental shelf, to the extent that these limits fall within the Second Schedule boundaries. The latter have been drawn far offshore to take account of the ambulatory nature of the limits of national jurisdiction as presently defined by the Convention on the Continental Shelf.

A single code of petroleum law is established. Part III of the Agreement provides that the administration of this common code in each Adjacent Area is to be by a "Designated Authority". In the case of the States, the Designated Authority is the State Minister for Mines. He is the administering authority for both the Commonwealth and the State legislation in the relevant Adjacent Area, and every action taken by him is taken twice, once under each statute. For example, the holder of an exploration permit over a specified area in fact obtains two permits in respect of that area, one under the Commonwealth Act, the other under the State Act, although both are contained on the one piece of paper issued by the Designated Authority.

The Agreement provides for consultation between Commonwealth and State Governments prior to the grant, renewal, variation, or transfer of all offshore oil and gas titles. ${ }^{103}$ The Commonwealth is to take account of certain of its constitutional functions, namely: trade and commerce, external affairs, taxation, defence, lighthouses, lightships, beacons and buoys, fisheries, and postal, telegraphic, telephonic and other like services, ${ }^{104}$ but no others. ${ }^{105}$ If the Commonwealth gives a decision inconsistent with the action proposed by the State Government, it is to specify the responsibility or responsibilities with respect to which the decision is given, unless it is "in the national interest" not to do so. ${ }^{106}$ The State Government is to accept and give effect to a decision of the Commonwealth with respect to one of the specified responsibilities. ${ }^{107}$

However, the Agreement provides that a condition may be included in a permit or licence requiring all or any petroleum produced to be refined in the State in whose Adjacent Area the permit or licence is located. Prior consultation between the Commonwealth and the State concerned is required, but the Commonwealth is not entitled to refuse to allow inclusion of the condition "unless it is reasonable in the national interest to do so having regard to the economic and efficient exploitation, processing and use of the petroleum resources to which the requirement would relate."108

The Agreement also provides for the sharing of revenues from offshore oil and gas production between the Commonwealth and the States. The Commonwealth is to receive a royalty of four percent on production, while all remaining royalties, between six and eight and one half

\footnotetext{
10: Supra, n. 98 at clause $11(1)$.

tor Id. at clause 11(2).

ios Id. at clause $11(3)$.

106 Id. at clause 11(4).

207 Id. at clause $11(5)$.

tow Id. at clause 14.
} 
percent, together with all moneys other than royalties, are to go to the State from whose Adjacent Area the revenues are raised. ${ }^{109}$

The preamble to the Agreement contains a declaration that the Commonwealth and State Governments are not, by the Agreement, derogating from their respective constitutional powers. ${ }^{110}$ This declaration is reinforced by the final clause of the Agreement itself, which reads as follows:

26. The Governments acknowledge that this Agreement is not intended to create legal relationships justiciable in a Court of Law but declare that the Agreement shall be construed and given effect to by the parties in all respects according to the true meaning and spirit thereof.

The continuance of the Agreement thus depends not upon any right to enforce its provisions, but upon continued acceptance of it by the parties.

The Agreement and the legislation enacted pursuant thereto have attracted criticism in Australia. Late in 1967, when the Commonwealth legislation was before Parliament, the Senate passed it only upon the condition that a Select Committee of the Senate be appointed to inquire into several of its aspects, one being "whether the constitutional conception underlying the legislation is consistent with the proper responsibilities of the Commonwealth and the States." This Committee published its report in 1971.111

The Committee concluded that "the constitutional conception underlying the legislation is inconsistent with what should be the proper constitutional relationship between the Parliament and the executive."112 Two reasons were given. In the first place, the Committee felt that there was a challenge to the exercise of the functions of Parliament in the conception of uniform. legislation, drafted by the executive arms of seven Australian Governments, being presented to Parliament as a fait accompli requiring mere formal legislative approval. The role of Parliament is restricted in this case to either total acceptance or total rejection of the legislation, as amendment will destroy the legislation's uniform character. In the second place, the system whereby the Designated Authority is given powers of undefined scope by two parliaments results in an executive administering important legislation without being wholly accountable to either parliament for its actions.

The Committee further concluded that "notwithstanding the advantages to the national interest which the legislation and its underlying conception has produced, the larger national interest is not served by leaving unresolved and uncertain the extent of State and Commonwealth authority in the territorial sea-bed and the Continental Shelf."113 One reason for this conclusion was that the lack of ministerial responsibility resulted from the uncertainty over constitutional authority. Another reason was that in respect of other matters arising in offshore areas, such as protection and conservation of natural features and resources, the doubt as to constitutional authority led to the inability to identify political responsibility, and hence inaction.

As early as 1968, it was pointed out that a difficulty inherent in the

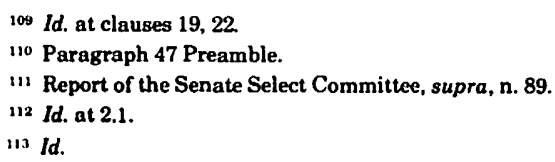


system of uniform legislation was the inflexibility which the involvement of seven different governments entails.114 This difficulty has in fact been encountered, and is evidenced by a failure of the Commonwealth and State Governments to agree upon uniform regulations to be made under the legislation. It is also evidenced by the failure to date of four State Governments and the Commonwealth Government to enact amendments to the legislation, agreed upon by all Governments pursuant to clause 6 of the Agreement in 1969. South Australia and Western Australia have nevertheless passed these amendments, with the result that, to this extent, the legislation applicable to the Adjacent Areas of these States is no longer uniform. ${ }^{115}$

Despite these criticisms, the Agreement remains a unique constitutional document in terms of Australian Commonwealth-State relations, and it seems that it has no counterpart in either the United States or Canada. The concept underlying the Agreement and the uniform legislation enacted pursuant thereto is one of cooperation, not by division of areas or nature of jurisdiction, but by concurrent action to establish a single administrative regime. In this respect it is the opposite approach to that adopted so far in the United States and Canada.

\section{The Federal Offer}

The offshore minerals dispute between Ottawa and the provinces has been simmering for more than a decade, beginning on the west coast when a seismic and exploration programme was undertaken by Shell Canada Limited. The granting by the federal government of $20,000,000$ acres off the shore of Nova Scotia again to Shell Canada Limited in 1963 intensified the dispute. At a federal-provincial conference in July 1965, then Prime Minister Pearson promised that, notwithstanding the Court's decision on a reference of the issue, the federal government would proceed by way of negotiation to reach agreement with the provinces. Following the decision in the Offshore Minerals Reference, Prime Minister Trudeau, in a statement on December 2, 1968, acknowledged Mr. Pearson's undertaking and announced the terms by which the federal government would carry it out.

The statement began with a recognition of practical difficulties flowing from the Court's decision in the Offshore Minerals Reference. For the purpose of delineating the offshore areas between federal and provincial ownership and jurisdiction the statement says:

There are certain difficulties in using for this purpose the boundaries described by
the Court, since it is difficult to ascertain what would have been considered as a bay
or harbour for the purposes of international or domestic law at the time most of the
provinces entered Confederation, and since the lines of low tide are shifting and
uncertain and our sea coasts are characterized by deep indentations, straits, innu-
merable islands, and inlets of various configurations.

The proposed solution was to draw arbitrary boundaries, called "mineral resource administration lines", based on the geodetic grid system and placed so as always to be well within the areas of federal jurisdiction in the territorial seas beyond the inland waters of the provinces. These "mineral resource administration lines" were not the same as the "baselines" from which the Canadian territorial sea would be measured but rather erred always on the federal side of such "baselines". In fact,

11 Thompson, Australia's Offshore Petroleum Common Code, (1968) 3 U.B.C. Law Review 1 at 15.

11 Report of the Senate Select Committee, supra, n. 80 at 6.271-6.282. 
in a few cases the areas enclosed by the resource administration lines would exceed even the then three-mile limit of the territorial sea.

On the landward side of the resource administration lines, the adjacent coastal provinces would each "administer any offshore mineral rights under federal jurisdiction" and would receive all mineral revenues. The administration and management of mineral resources seaward from the resource administration lines would remain with the federal government. With respect to the revenues derived from these seaward areas, the federal government would place a half share in a single national pool which would be available to the "provinces concerned" to be shared on a basis acceptable to the provincial governments.

The various objectives which the federal government sought to achieve in making its offer to the provinces can be identified as (1) a speedy settlement, (2) an efficient and practical administrative arrangement and (3) a long-term solution which would be accepted by the coastal provinces as an equitable response to their claims that the seabed resources belonged to them.

In retrospect, some three and a half years later, it seems that none of these objectives is being accomplished. Certainly. recent evidence belies any expectations of an early settlement of the problem. In fact, the controversy has never abated and seems to be sharpening. In 1968 British Columbia passed B.C. Reg. 105/68 under s. 89(g) of the Petroleum and Natural Gas Act, 1965, constituting all seabed resources in the territorial sea and the continental shelf lying off the coast of British Columbia a provincial Crown reserve. Nova Scotia has just introduced Bill No. 124 in its 1972 Session of the Legislative Assembly whereby the marine area, defined as the seabed and subsoil of any area covered by seawater, the subsoil of Sable Island and all minerals including oil and gas situate therein are declared to be, and to have been at all times, vested in the Crown in the right of the Province. We understand that Newfoundland is preparing similar legislation. Quebec continues to take the position that it owns its offshore areas and to ignore the Offshore Minerals Reference and the federal offer..$^{116}$

The aspects of the federal offer which might be claimed to contribute to an efficient and practical administrative arrangement are the use of the geodetic grid system and the drawing of resource administration lines. Undoubtedly, the use of the geodetic grid system is advantageous and preferable to following the sinuosities of the coast line. In fact, this system is now used in British Columbia for both offshore and onshore petroleum and natural gas permits and leases.

But we are unable to conclude that the system of resource administration lines will contribute to an efficient and practical administration. Avowedly they were designed to avoid the necessity of legally defining the boundary between the inland waters of the provinces and the territorial sea. We asked ourselves how, within the framework of Canadian constitutional law, this arbitrary delineation between federal and provincial administrations can be made to work. Since it is well-estab-

136 Since the writing and presentation of this paper, it has been reported (Vancouver Sun, Thursday, August 3 1972) that the Premiers of Quebec, Newfoundland, and the Maritime Provinces have agreed to take a united front against the federal government on offshore mineral problems. Without withdrawing from their position that the Provinces are entitled to the offshore mineral resources, the Premiers decided that a "suitable regional agency" with representation from the five provinces and the Dominion "would be desirable" to administer certain aspects of the offshore oil and gas industry. 
lished that there cannot be delegation of legislative powers from either the federal Parliament to the provincial Legislatures, or vice versa, some ingenuity will be required to erect a legislative and administrative framework that will legally support the zones created by the resource administrative lines. Is it the intention of the federal offer to have coastal provinces administer the resources on the landward side of the resource administration lines under federal legislation or under provincial legislation? If under the former, how can this legislation be given validity with respect to the areas which are legally within the inland waters of the province? If under the latter, how can the provincial legislation validly regulate the areas within the territorial sea? Possibly the federal government contemplates that mirror legislation on the Australian style will be enacted by Parliament and the provincial Legislatures. But such mirror legislation is enormously difficult to achieve even if there are willing parties anxious to reach agreement, and such a system must be carefully designed so as to minimize the impact of its characteristic inflexibility.

Even if the envisaged constitutional impediments were non-existent or can be evaded, the resource administration lines proposed by the federal government still create one major difficulty. This difficulty is that the resource administration lines will result in an excessive fragmentation of jurisdictions over the offshore mineral resources. The Australian solution has been lauded because it provides one system of laws applicable to leasing and regulation of operations in the offshore regions through its mirror legislation. A defect in the Australian system, however, is that this common code is administered in each offshore area adjacent to a state by that state's administrative officials and machinery. Consequently there are no less than seven separate administrations regulating offshore leasing and operations with all the inconsistencies in application of the mirror legislation that such fragmentation usually entails. When we turn to examine the Canadian position, a first reaction to the Court's decision in the Offshore Minerals Reference could be that Canada has avoided the problems arising from fragmented offshore jurisdictions because the offshore areas are given exclusively to the federal Parliament and the federal government for legislative and administrative purposes. But the system of resource administration lines required us to take a second look. Now we see that a substantial portion of the offshore areas, estimated to be between $9 \%$ and $10 \%$ of the total Canadian offshore regions, will be administered by the various coastal provinces under their respective legislative schemes. In result, we will have one federal and five provincial administrations operating off the east coast of Canada under six different legislative schemes. When the French administration and legislation for the offshore areas attached to the islands of St. Pierre and Miquelon and the United States federal and State of Maine administrations and legislation are added in the south, the fragmentation of the east coast waters exceeds all reasonable bounds.

Fragmentation of jurisdiction produces inefficiency in more than one aspect. From the purely administrative point of view, there is the inefficiency for companies and for the public resulting from maintaining half a dozen administrations where one would do equally as well. From the point of view of public interest, there is the inefficiency of realizing less public benefits than might otherwise be the case. It seems apparent 
that oil companies, because they are often in a buyer's market when acquiring petroleum rights, can play one jurisdiction off against another. The fragmented administrations in the Canadian offshore can be expected to result in competition among governments for exploration and development capital which will be detrimental to the public interest.

In short, we conclude that the system of resource administration lines proposed by the federal government does not clear up uncertainties about boundaries and jurisdiction and results in a highly impractical and undesirable fragmentation of administration in the offshore regions. Of course this conclusion does not apply in the case of the west coast offshore region because only one province, British Columbia, will be in competition with the federal regime in that case.

The third objective of the federal proposal is to obtain a longrange settlement which will be accepted as fair and equitable by the coastal provinces. The federal method for attaining this objective is to give to the coastal provinces the resource revenues accruing from the landward side of the resource administration lines together with a share, on some acceptable basis, of $50 \%$ of the resource revenues realized by federal government on the seaward side of the resource administration lines. It is not clear in the federal proposal whether this national pool is to be shared by all the Canadian provinces or merely by the coastal provinces. That this offer is not acceptable as a fair and equitable solution to the claims of the coastal provinces has been made abundantly clear in negotiations since the Offshore Minerals Reference, at least so far as we can tell from newspaper accounts and speculations about these negotiations. One reason why the revenue sharing proposals are greeted with less than unbounded enthusiasm is that natural resource revenues are taken directly into account in calculating the equalization payments which are made annually under the federal-provincial agreements. One rough calculation indicated that Newfoundland would have to receive as its share of resource revenues under the federal proposal in excess of $\$ 100,000,000$ per annum before it would gain any net benefit over its present position under the equalization formula. In any event, it is not difficult to understand that the maritime provinces and Quebec may be equally as interested in the secondary effects of resource development as in direct revenues. It is these secondary effects that are productive of viable local enterprises and employment and these secondary effects can be controlled only through the exercise of legislative jurisdiction over the resource. Direct revenues, on the other hand, can only be used as artificial stimulants to economic development. We know that the regional economic expansion programme for the maritime provinces is not entirely a demonstrated success. Why would maritimers regard the receipt of a share from a national pool of offshore resource revenues any different from receipt of equalization payments or subsidies under the regional expansion programme? Regional ambition and regional pride will best be served by regional control of resources. Put in these terms, it is not surprising that the maritime provinces and Quebec are rejecting the federal offer.

\section{Some Alternative Solutions}

To be preferable, any alternative solution should not delay settlement of the offshore dispute and should provide an efficient and practical system of administration of resources within a scheme that is more 
acceptable to the coastal provinces than the scheme presently offered by the federal government. The key to an early settlement is that the solution be both efficient and acceptable and therefore it is these criteria that any alternate solution must meet. We consider it worthwhile to analyze alternatives though we cannot possibly anticipate many factors which might be influential or even critical. Our reason is that we believe that any offshore solution must ultimately meet the test of general public acceptance throughout Canada and therefore there should be open public questioning and discussion of the issues.

In seeking a demarcation line for administration purposes in the east coast region, we conclude that the most efficient and practical division is between exploration and development operations conducted on land and those conducted in the offshore waters. This division is dictated by many considerations. Offshore operations are characteristically more costly than those on shore; they depend on different techniques and equipment; they are undertaken in a different kind of natural environment than onshore; and, while they do not come into conflict with other surface uses as in the case of land, they must be regulated for other maritime uses such as shipping and come under a special regime of international law for these purposes.

The geodetic grid system can be used to draw the demarcation line. Leasable blocks along this line will include both land and water-covered areas. Whether a particular block would be assigned to one side of the line or the other would depend on whether it would likely be explored and developed by land-based operations or by water-based operations.

Any demarcation line which does not coincide exactly with the legal boundary separating the low-water mark and the inland waters of a province from the territorial sea must contain some admixture of provincial and federal areas, assuming that the Offshore Minerals Reference is accepted as a correct statement of the law. The federal "resource administration lines" favour the provinces by including substantial federal areas within the provincially-administered regions. A demarcation line dividing onshore and offshore operations, such as we propose, would have the effect of placing substantial provincial areas in the offshore region. This fact must be taken into account in proposing alternate schemes that would be acceptable to the provinces, remembering that an attractive part of the federal offer so far as the provinces are concerned is the inclusion of substantial federal areas on the provincial side of the resource administration lines.

Because any demarcation line other than the legal boundary involves an admixture of federal and provincial areas, there must be created a legal framework which will permit an admixture of federal and provincial jurisdictions. Before examining how this framework can be created, we wish to note a criticism made by the Senate Committee in Australia when they addressed their minds to the problem of defining a boundary between State and Commonwealth jurisdictions. The Australian approach, like the federal offer and our alternative solutions, sought to beg the question of location of the legal boundaries between the States and the Commonwealth in the offshore. The Australian scheme employed the mirror legislation technique. The Senate criticism was that, no matter how expedient it may be to evade a determination of legal boundaries, the issue must sooner or later be faced and its resolution should not be postponed. The problem is that the mirror legislation which evades 
the boundary issue, so far as petroleum leasing and operations are concerned, cannot take account of every jurisdictional question that may arise. For example, the mirror legislation does not cover all pollution and environmental control matters and therefore the issue remains as to whether particular State or Commonwealth statutes are governing in these matters, and this issue cannot be resolved without a determination of legal boundaries or further mirror legislation. We take this criticism as a warning that the necessity of legally defining the precise boundaries between Canada and its coastal provinces will not disappear merely because demarcation lines are drawn dividing areas between Canada and the provinces for the administration of seabed resources. Nevertheless, the establishment of some arbitrary demarcation line is highly desirable at the present time because the definition of legal boundaries between Canada and its coastal provinces, if judicially accomplished and taking into account all the special circumstances, would take a lifetime of litigation. This criticism can be met in part by carefully specifying in the mirror legislation whether particular ancillary jurisdictions are to be exercised federally or provincially, and by enacting the necessary adoptive legislation to give effect to the arrangement. We will have more to say later in this paper about the application of ancillary laws to offshore operations. ${ }^{117}$

It is well established in Canadian constitutional law that legislative jurisdiction cannot be delegated by Parliament to a provincial legislature or vice versa. Therefore, it will not be sufficient for the federal and provincial governments merely to make an agreement that federal areas on the landward side of the resource administration lines will be administered by the adjacent coastal province under its petroleum legislation, nor could provincial areas be turned over to federal administration under federal legislation by such means. On the other hand, federal legislation can validly incorporate provincial legislation, even as it may be varied from time to time by the provincial legislature. In the Coughlin Case ${ }^{118}$ the Motor Vehicle Transport Act ${ }^{119}$ was upheld as valid federal legislation. This Act gave to a provincially-appointed transport board the power to licence extra-provincial truck carriers in accordance with the same provincial laws and regulations under which the board was licensing intra-provincial carriers.

Therefore, by carefully drawn legislation Parliament may adopt for federal areas landward of the resource administration lines the administrative agency and legislation of the adjacent coastal province under which it controls its offshore petroleum leasing and operations. Similarly, a coastal province could enact legislation adopting the federal administration and petroleum legislation for provincial offshore areas.

By this legislative technique one solution which would accomplish our objective of dividing jurisdiction between land-based operations and water-based operations would be for the coastal provinces to pass legislation adopting the federal offshore administration and legislation for all the provincial areas offshore from the demarcation line. Alternatively, Parliament could assign the entire offshore area of the territorial sea and the continental shelf to the provinces by similar adoptive legislation.

\footnotetext{
"17 See infra.

110 Coughlin v. Ontario Highway Transport Board [1968] S.C.R. 569, 68 D.L.R. (2d) 384.

119 1953-54 (Can.) c. 59.
} 
This alternative would not remove our objection of excessive fragmentation of legislation unless the coastal provinces were to pass mirror legislation which Parliament could adopt. A further alternative would be for Parliament to pass mirror legislation along with the coastal provinces, thereby eliminating the adoptive approach altogether.

We prefer the adoptive approach wherever it can be used. Unlike the mirror approach, it does not fetter the ability to amend the operating legislation and regulations, for, whereas the mirror approach requires that all jurisdictions agree to amendments, the legislature whose legislation is adopted can, by itself, amend its provisions and enact and amend regulations.

A further objection to the mirror approach, as used in Australia, is that it establishes a separate administration for the adjacent area of each State. This objection could be met by choosing either the federal administration or a single provincial administration as the sole administering agency for the entire offshore region. A preferable scheme might be to establish a distinct independent agency for administrative purposes such as is familiar to Canadians in such an institution as the Atomic Energy Board of Hydro-Quebec.

But adopting the engineer's confident philosophy that if we know what we want, we can find a way to attain it, we can put aside these questions of technique and grapple with the fundamental problemnamely, to find the kind of arrangement that will be acceptable to the federal government and the provinces.

If we accept the premise, which seems inescapable on the facts known to us, that receipt of resource revenues is not the prime benefit which either the federal government or the coastal provinces seek from the exploitation of the seabed resources, an answer can be found only in terms of an arrangement which satisfactorily distributes control over the seabed resources among the affected parties. This control is not control over defense, or shipping, or telecommunication systems, or international relations, or over inter-provincial works and undertakings such as pipelines, for control in each of these cases is already clearly allocated on a national basis to the federal authorities. ${ }^{120}$ The control that is in issue relates to such matters as the exercise of proprietorship over the seabed resources with the leverage that such proprietorship entails; the exercise of influence over the secondary effects that follow exploration and development such as the location of oil company offices, maintenance and servicing operations, and storage, processing and refining facilities; and the exercise of authority over the safety, pollution and environmental aspects of exploration and development. Dispersal of such control among numerous governments creates the fragmentation and inefficiency which we assigned as a major defect of the federal offer. But an implicit assumption of a federal system of government is that there are divergent regional interests that are best controlled at the regional level. The trick is to strike the proper balance between federal control and regional control, and such balance must be sought as a continuing process because regional interests change and inter-

\footnotetext{
120 We believe, along with the dissenting judgments in the cases of U.S. v. California and U.S. v. Texas (see supra, n. $79,80)$ that there is no inconsistency between federal responsibility under international law for the offshore regions and provincial control over the explorative aspects of the seabed resources just as Canada can discharge its international responsibilities with respect to air traffic over land owned and regulated by the provinces.
} 
change with federal interests. Opposed to this requirement of regional control over vital regional interests is the need for an efficient and practical administration. How are these opposites to be reconciled?

The federal offer should be attractive to the coastal provinces in terms of control because it gives them a substantial amount of federal territory-estimated to be about 9 or $10 \%$ of the total offshore area. But it is not, the reason being that exploration off the east coast to date indicates that the first commercial deposits of oil and gas will be located on the federal side of the resource administration lines (assuming that the federal claim to the mineral resources of Sable Island is established). The provincial authorities now are confronted with the possibility, and, in the case of some provinces, the probability, that the regions they would administer landward of the resource administration lines will contain no commercially-exploitable oil and gas. They naturally insist that they should have control over the entire adjacent offshore area. The federal position must also be that federal control should prevail over the offshore region that has been baptized as federal property and subject to exclusive federal jurisdiction by the Offshore Minerals Reference.

The way out of this confrontation must be some mechanism for joint control over the offshore resources. There is ample precedent for such joint control on the side of private business in the joint operating and unitization arrangements that are so common for securing a unified control and administration over mineral properties owned by different companies. There is also precedent taking shape in the international sphere where Canada is a strong advocate for an international agency that will manage the resources of the ocean bottoms for all nations. Why cannot such mechanisms be instituted within the domestic constitutional framework? Various instrumentalities for cooperation between the federal and provincial governments on marine sciences and technology in the offshore regions have already been put forward in the Science Council report entitled Ad Mare: Canada Looks to the Sea, ${ }^{121}$ though these models place direct political responsibility on the federal government, a step that might not be acceptable to the provinces.

We recognize that any proposal whereby joint control is instituted entails the establishment of a control body that, because it must answer to more than one political entity, is not fully answerable to any one, with a consequent weakening of political control. But we do not believe this weakness to outweigh the weakness inherent in the current federal proposal or on any alternative proposal that results in fragmentation of jurisdiction over the functional unity of resource development in the offshore regions.

Now we can postulate the kind of alternative solution we favour.

1. It should divide jurisdiction between onshore and offshore operations by a line based on the geodetic system of survey.

2. Within the offshore region there should be a single administrative agency. The choice could be the present federal offshore administration in the Department of Energy, Mines \& Resources, a provincial administration, or a newly-created independent agency.

3. The legislative framework, whether on the mirror principle or the adoptive principle, or a combination of these, should retain a 
maximum of flexibility so that amendments of the terms governing permits and leases, work obligations, operating procedures, and fees, rentals and royalties can be achieved without the necessity of unanimous consent by all the legislative bodies concerned.

4. There should be a policy-making system that permits control over offshore exploration and development to be shared by all the governments concerned on an equitable basis. Such a system must be elaborately tailored to provide voting balance among federal and provincial representatives, to define those questions that are of such significant policy content as to require answers to be given by this system rather than by the administrative agency, and to establish the relationship between this system and the governments and legislative bodies to which it must answer.

5. Ultimate political responsibility should probably rest on the basis that any participant, federal or provincial, can withdraw from the system. This right of withdrawal is the legal underpinning in the Coughlin Case 122 $^{22}$ of recognition that a legislature may validly adopt as its own the legislation-making of another legislature. It will also legitimize the democratic nature of the system.

6. Such a system might comprise a policy committee or board made up of four federally-appointed members and five provinciallyappointed members, one appointed by each coastal province. On some issues the provincial voting, as in unitization agreements, could be based on a determination of contributed acreage. There are many possibilities to be explored. ${ }^{123}$

\section{Ancillary Problems}

This presentation of alternative possibilities for settling the offshore issues leaves two problem areas to be discussed before this analysis of Canada's offshore problems can be said to be complete. These are the problems of applying various ancillary federal and provincial laws in the offshore regions and the problem of defining provincial boundaries.

\section{(a) Application of Laws to Offshore Areas}

A comprehensive legal regime governing offshore oil and gas operations is not achieved simply by the enactment of a statute containing a petroleum code. A wide range of other types of laws must also be made to apply to these operations, for example, criminal law, revenue law, welfare legislation, industrial legislation, environmental control legislation, immigration laws, and navigation and shipping laws, to name but a few. In fact, what is required is a body of laws similar to those governing oil and gas operations on land.

The present position in Canada with respect to the application of laws other than petroleum laws to offshore oil and gas operations is most confused. There would appear to be two reasons for this. In the first place, the question of application of laws cannot be fully determined until the constitutional issue is resolved whether the federal parliament, the provincial legislatures, or both, have jurisdiction to legislate with respect to offshore areas. Secondly, even after this first hurdle is cleared, there remains in each case a question of interpretation whether the terms of any particular statute are such as to make it applicable to offshore areas. Most federal and provincial statutes appear to have been drafted without

122 See supra, n. 118.

${ }^{123}$ Resource revenues from the offshore region can be shared on any acceptable basis. 
consideration being given to whether or not they should apply beyond land boundaries, and so it is usually only by accident that a statute will be made expressly applicable to offshore areas.

In order to obtain some indication of how offshore operators are presently dealing with this problem of application of laws, we sent a brief questionnaire to six major oil companies engaged in offshore operations. The questionnaire is reprinted as an appendix to this paper. Five replies to it were received, and these show the dimension of the problem. All companies seemed prepared to comply with the federal legislation listed. However, when it came to provincial and municipal laws there were substantial differences in both opinions and present practice. Two companies stated that they are presently complying with all the categories of provincial and municipal laws listed. So did a third, but comments made by this company suggest that this practice may be the result of convenience rather than its opinion on the legal questions involved. The fourth replied that while it complied with provincial workmen's compensation laws and safety regulations, there was a dispute between the company and Nova Scotia over the applicability of that province's sales tax legislation to goods purchased for use on Sable Island. That company also stated that in its opinion, where drilling operations are conducted on the continental shelf, these operations are outside provincial jurisdiction. The fifth company stated that to date it has not concerned itself with any of the provincial legislation included in the questionnaire.

As to the question whether the Canadian Criminal Code applies to activities upon offshore installations (floating or fixed), differences of opinion were also apparent. Of the three answers received to this part, one was yes, another was yes but with reservations, and the third was yes for such operations upon Sable Island and in the territorial sea, but no in respect of all other offshore operations.

We will not attempt to offer an opinion upon the current state of applicability of the various laws to oil and gas operations offshore from Canada. It is our intention merely to illustrate the problem, and then to go on to point out how solutions to the problem have been approached in the United States and in Australia.

In the United States, the Outer Continental Shelf Lands Act of 1953, which established the petroleum code applicable to offshore oil and gas operations seaward of the areas granted to the coastal states by the Submerged Lands Act of 1953, also extended a body of law to these offshore areas, consisting of: (a) the constitution and the laws, and the civil and political jurisdiction, of the Federal Government; (b) the regulations, rules, and operating orders of the Secretary of the Interior; and (c) in the absence of applicable Federal law or adequate regulation by the Secretary, the civil and criminal laws of the State adjacent to the offshore area. Such State laws were adopted as Federal law for the area of the continental shelf that would be within the boundaries of the State if such boundaries were extended seaward to the edge of the continental margin. ${ }^{124}$ Some cases have arisen requiring interpretation of these provisions, ${ }^{125}$ but none of these have suggested that there is any serious

124 Outer Continental Shelf Lands Act. supra, n. 82 at s. 4.

125 Gravois et al. v. Travellers Indemnity Company et al. 173 So. (2d) 550; Continental Casualty Company v. Associate Pipe \& Supply Co. Inc. et al. (1967) 279 F. Supp. 490; Ocean Drilling and Exploration Co. et al. v. Berry Bros. Oilfield Service Inc. (1967) 377 F. (2d) 511; Rodrigue et al. v. Aetna Casualty \& Surety Company et al. (1969) 395 U.S. 352. 
difficulty inherent in the system adopted for the application of laws.

In Australia, Part II of the offshore oil and gas "mirror" legislation provides for the application in areas adjacent to a State or Territory of the general body of laws, both State and Commonwealth, in force in a State or Territory. The legislation also provides for the vesting in State courts and the conferring on Territorial courts of jurisdiction in matters arising under the body of law so applied.

At first glance this may appear a neat solution to the problem of application of laws, arrived at without the necessity of determining the respective limits of Commonwealth and State jurisdiction in offshore areas. However, the matter of drafting the provisions of the "mirror" legislation in terms which are appropriate to achieving the desired result has proved a formidable task. The effectiveness of the relevant sections of the legislation, ${ }^{126}$ as enacted in 1967, has been seriously questioned, ${ }^{127}$ and in 1969, the Commonwealth and the States agreed to amendments of these sections. To date, however, only South Australia and Western Australia have enacted the agreed amendments. ${ }^{128}$

The other difficulty involves limitations upon the competence of both Commonwealth and State Parliaments to make legislation applicable to offshore areas. The doctrine of colonial extra-territorial incompetence applies to the Australian States (and also to the Canadian provinces). Furthermore, in Australia, all Commonwealth legislation must be passed pursuant to one of the Commonwealth heads of power listed in the Constitution. We shall not discuss these complex doctrines in any more detail, but merely point out that both may impose limitations upon any generalized scheme for the application of laws to offshore areas.

\section{(b) Provincial Boundaries}

The question of offshore jurisdiction is a complex one in the context of a federal state like Canada. A final decision, either that the federal government has jurisdiction seaward of the ordinary low-water mark outside of provincial inland waters, on all coasts, or instead, that the provinces have jurisdiction over the seabed under the territorial sea as in the United States, only opens the door to further issues.

If the former comes to pass there will have to be a further decision as to what exactly are inland waters. When each of the provinces came into Confederation inland waters were defined by international law as coastal waters enclosed by lines of six marine miles. ${ }^{129}$ Later, at the 1958 Geneva Convention they were enlarged to waters enclosed by lines of twenty-four marine miles. ${ }^{130}$ In addition, federal legislation has implemented the system of straight baselines provided for by the 1958 Geneva Convention for the delimiting of the territorial sea, and the waters between land and the baselines are now considered inland waters. ${ }^{131}$ In the eyes of international law these additional inland waters are added to Canada. It is open to argue that to consider waters added to Canada since a province joined Confederation as belonging to the province would amount to a redefinition of the provincial boundary which is

\footnotetext{
126 Petroleum (Submerged Lands) Act 1967, supra, n. 102 at 88. 9-13.

12: Report of the Senate Committee on Off-Shore Petroleum Resources, (1971), Chapter 16.

12* Petroleum (Submerged Lands) (Amendment) Act 1969, (S.A.), (W.A.).

129 Oppenheim. International Law 505 (8th ed., 1955).

130 Geneva Convention on the Territorial Sea and the Contiguous Zone (1958), Article 7(5).

131 Territorial Sea and Fishing Zones Act, R.S.C. 1970. See also Crosby, supra, n. 2 at article 5(1).
} 
fixed by the BNA Act. ${ }^{132}$ On the other hand, the decision in the Offshore Minerals Reference leaves untouched the provincial contention that the term "inland waters" refers to what is currently recognized as inland waters by international law.

As part of the inland waters problem, the question of "historic waters" will have to be settled. If a province can establish historic title, before joining Confederation, to certain coastal waters then the limits of its jurisdiction are not defined by the international definition of inland waters, i.e., by convention or straight baselines.

Another part of inland waters which may yet raise jurisdictional problems are "public harbours", which by s. 108 of the B.N.A. Act have been expressly transferred to the federal government. There may still be some question, in the absence of agreement, as to the extent of the "harbour" and the nature of the interest transferred, particularly with respect to seabed resources. ${ }^{133}$

A similar set of questions would have to be answered if the provinces were to obtain jurisdiction over the seabed of the territorial sea. The question is whether the provinces would receive the three-mile territorial sea, accepted when each joined Confederation, or the twelve-mile territorial sea recently established by federal legislation. ${ }^{134}$ In any case the point from which the seaward boundary of provincial jurisdiction is to be measured would have to be decided. This problem has been dealt with in some of the coastal states of the United States. While the individual states have ownership of submerged lands to a distance of three miles seaward by virtue of the Submerged Lands Act of $1953,{ }^{135}$ the point from which the distance is measured has been a contentious issue. In 1965 a decision of the United States Supreme Court provided that the three-mile seaward boundary is to be measured from the actual location of the mean low-water mark, as modified from time to time by either natural or artificial means. ${ }^{136}$ The Court pointed out that the inequity to the United States of allowing California to effect changes in the boundary by making artificial changes in the coastline are met by the ability of the federal government to protect itself by its powers over navigable waters. ${ }^{137}$ It is interesting to note that the Court rejected California's claim to straight baselines under Article 4 of the Geneva Convention on the Territorial Sea and Contiguous Zone on the ground that they can be established only by action of the national government.

If the question as to the ownership of offshore lands is settled on all coasts in favour of the federal government, from the low-water mark seaward, outside of provincial inland waters, and none of this area is turned over to provincial administration, the interprovincial boundary issue will be much simplified. However, there might still be disputes between some of the east coast provinces over certain inland waters. While New Brunswick and Nova Scotia are defined by a line drawn in the middle of the Bay of Fundy, ${ }^{138}$ and the boundary between Quebec and

\footnotetext{
132 Re Dominion Coal Co. and County of Cape Breton (1963) 40 D.L.R. (2d) 593.

1:33 Laforest, Natural Resources and Public Property Under the Constitution at 49-68 (1969).

134 Territorial Sea and Fishing Zones Act, supra, n. 131.

13s Supra, n. 81

236 United States v. California 382 U.S. 448.

137 381 U.S. 176 at 177.

t38 Laforest, supra, n. 133 at 86.
} 
New Brunswick is drawn in the middle of Bais des Chaleurs, ${ }^{139}$ inland waters were not so clearly defined elsewhere.

Should the federal resource administration lines be accepted on the east coast, or should the coastal provinces obtain title to or jurisdiction over the seabed resources beneath the territorial sea by judicial decision or political settlement, interprovincial boundaries will have to be drawn. The method used to delimit the respective areas would hopefully derive from a mutual agreement. It has been reported that the four maritime provinces and Quebec have reached an understanding among themselves as to the interprovincial boundaries to be recognized on the seabed, and that they, and oil companies seeking provincial permits, are presently respecting this agreement. ${ }^{140}$

The principles upon which the understanding was reached have not been made clear and it may be helpful to consider the practice of another federal state having the same problem.

The common practice in the United States has been interstate boundary agreements ${ }^{141}$ with the result that litigation between two states as to their lateral ocean boundaries has never come before the courts. ${ }^{142}$ Under the interstate agreements, joint commissioners have been appointed to engage in common fact-finding to agree on a boundary, which is then adopted by parallel state legislation or ratified as a formal instrument by the state legislatures. These agreements then require congressional consent. ${ }^{143} \mathrm{~A}$ similar arrangement among the maritime provinces and Quebec would be in order, subject to compliance with particular Canadian constitutional requirements.

If judicial determination of boundaries were required the court would have to refer to domestic law in the form of statutes, precedents and treaties. It may also be necessary to consider the common law principles of riparian rights, including the common law of accretion, and past provincial practice in delimiting the beds of streams and lakes. However, domestic law contains few rules which are directly relevant to the delimitation of offshore sea boundaries, and another source of relevant principles is necessary. The United States has drawn upon international law as a source of applicable law in both interstate and federal-state boundary disputes. ${ }^{144}$ These provide convenient guidelines for settling a thorny problem. Hence in the United States the median-line principle is considered applicable to the delimitation of lateral offshore boundaries between the individual states. ${ }^{145}$ Because the east coast provinces are located in such a manner that a simple extension of land boundaries would result in an inequitable distribution, the median-line method would be a starting point to be modified in places by historic title or special circumstances.

\footnotetext{
130 Id. at 87.

140 E.g., the agreement is referred to in an article by Pierre-C. O'Neill in Le Devoir, November 8, 1967.

14 Griffin, Delimitation of Ocean Space Boundaries Between Adjacent Coastal States of the United States 148 (1968).

$142 \mathrm{Id}$.

143 Virginia v. Tennessee (1893) 148 U.S. 503 at 528.

.14 Griffin, supra, n. 141 at 149.

14: Shalowitz, 1 Shore and Sea Boundaries 47 (1962).
} 


\section{CONCLUSION}

This analysis of Canada's offshore problems should have demonstrated that the issues facing lawyers and public administrators respecting the offshore regions are at least of the same order of magnitude as technological and economic ones-indeed they are far more complex and difficult.

Complexity can often be met only by bold and innovative solutions. On the other hand, if one seeks refuge in established practices and procedures, maybe the ideal is simply to maintain the status quo whereby both federal and provincial authorities assert overlapping jurisdictions in the offshore areas. Oil companies need only duplicate their responses to bureaucratic demands. Their work credits satisfy the work obligations of both the overlapping permits. The companies are accustomed, even in Alberta, to submit to overlapping regulations of such facilities as pipelines. When production comes, they can pay royalties twice, too! Doubled, the federal royalty scale would be close to matching the $16^{2 / 3} \%$ royalty applicable to federal continental shelf production in the United States. Such doubling of payments might provide an answer to the mounting criticism in Canada that federal royalty rates are inadequate.

Should the oil companies rock the jurisdictional boat that floats over Canada's seabed resources? 
APPENDIX I. QUESTIONNAIRE

OFFSHORE OPERATIONS-CANADA (including Sable Island)

(iv) Safety

regulations

(v) Fire

regulations

(vi) Environmental

regulations

C. MUNICIPAL

(i) Assessments

and rates

ALSO: Do you regard activities upon offshore installations (floating and/or fixed) as 